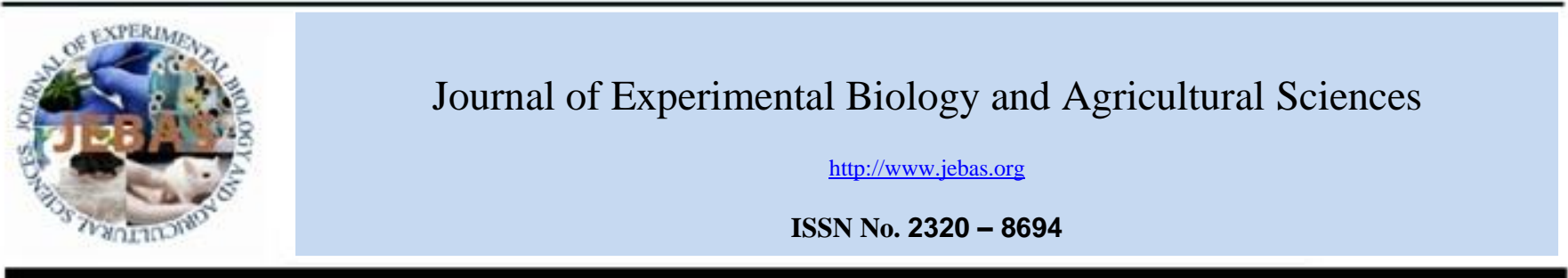

\title{
RABIES, A VACCINE PREVENTABLE DISEASE: CURRENT STATUS, EPIDEMIOLOGY, PATHOGENESIS, PREVENTION AND CONTROL WITH SPECIAL REFERENCE TO INDIA
}

\author{
Rajendra Singh $^{1 *}$, K.P. Singh ${ }^{2}$, M. Saminathan ${ }^{1}$, Vineetha $S^{1}$, G.B. Manjunatha Reddy ${ }^{3}$, \\ Madhulina Maity ${ }^{1}$, Susan Cherian ${ }^{1}$, K. Dhama ${ }^{1}$
}

\begin{abstract}
${ }^{1}$ Division of Pathology, ICAR-Indian Veterinary Research Institute, Izatnagar-243122, Bareilly, Uttar Pradesh, India
${ }^{2}$ Centre for Animal Disease Research and Diagnosis (CADRAD), ICAR-Indian Veterinary Research Institute, Izatnagar-243122, Bareilly, Uttar Pradesh, India

${ }^{3}$ ICAR-National Institute of Veterinary Epidemiology and Disease Informatics, Bengaluru, Karnataka, India
\end{abstract}

Received - January 13, 2018; Revision - February 04, 2018; Accepted - February 17, 2018

Available Online - February 20, 2018

DOI: http://dx.doi.org/10.18006/2018.6(1).62.86

\begin{tabular}{lll}
\hline KEYWORDS & ABSTRACT \\
Rabies & Rabies is a fatal viral zoonosis caused by lyssavirus. It affects warm blooded animals and humans. It is \\
more prevalent in Asia, Africa and the Latin American countries. Although the exact magnitude of the \\
disease is not reliably known, some studies estimated that 174 lakh persons are bitten by dogs and \\
approximately 20,000 persons succumb to the disease annually. Global Alliance for Rabies Control \\
estimated annual economic losses because of rabies in India is more than 2000 US dollars, mostly due to \\
premature deaths, cost of vaccines, lost income for victims of animal bites and other costs. In spite of \\
policies aimed for elimination of rabies, the same continues its reign as the most feared among the \\
incurable human diseases, having rare declining trend. Being a neurotropic virus with variable \\
incubation period within the host, death becomes inevitable once the pathogenesis has started with \\
discernible clinical symptoms. Prompt diagnosis of the suspected cases is indispensable for effective \\
cure and control of rabies. The diagnostic procedure recommended by OIE and FAO is \\
direct fluorescent antibody test (dFAT). More than 3 million vaccine units are used annually as post- \\
India
\end{tabular}

* Corresponding author

E-mail: rajendra_singh5747@ rediffmail.com (Dr Rajendra Singh)

Peer review under responsibility of Journal of Experimental Biology and Agricultural Sciences.

Production and Hosting by Horizon Publisher India [HPI] (http://www.horizonpublisherindia.in/).

All rights reserved.
All the article published by Journal of Experimental Biology and Agricultural Sciences is licensed under a Creative Commons Attribution-NonCommercial 4.0 International License Based on a work at www.jebas.org.

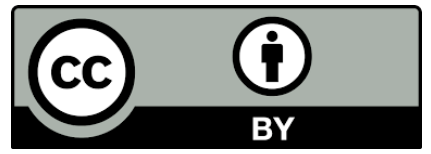




\section{Introduction}

Rabies is a fatal disease posing serious public health concern, particularly in Asia and Africa (Singh et al., 2017). The word rabies has its origin from the Latin word 'rabere' which means 'to be mad'. History and clinical recognition of rabies dates to twenty third century $\mathrm{BC}$, where the first reference to animal rabies was recorded in the laws of Eshunna in Mesopotamia. Demonstration of neurotropism of the virus and the development of a rabies vaccine followed by its successful administration by Louis Pasteur during 1980's was a great triumph in the history of rabies. With the advent of science and modern understanding of the virus and its immune protection, highly effective vaccines for the prevention and control of rabies have been developed. Despite the availability of safe and effective vaccines and understanding of the disease, the dog-mediated rabies causes approximately 61,000 annual deaths worldwide in humans, of which about 16,450 cases occur in India alone (WHO, 2013). The reasons being lack of awareness about the bite wound cleaning, vaccination, use of antirabies immunoglobulins in bite cases, non availability of the vaccines in remote places, etc. Due to under-reporting, rabies falls among the eighteen Neglected Tropical Diseases (Hampson et al., 2015). The true burden remains underestimated as the diagnostic facilities and disease surveillance are restricted in both animals as well as humans. Regardless of the concerted efforts made on global scale, with enhanced focus on implementation of control schemes and awareness programmes, the disease remains endemic in Asia and Africa, contributing 95\% of reported cases worldwide (WHO, 2013). Rabies is completely preventable through exhaustive mass immunization of dogs and post-exposure prophylaxis (PEP) of humans as well as animals. It is imperative to create awareness among the vulnerable population to avoid exposure (Balaram et al., 2016).

Rabies virus (RABV) induces mild to severe neurological signs described as furious and dumb forms, followed by paralysis, coma and death. The rabies virus circulates in two interrelated cycles, the first one involving domestic mammals (predominantly dogs and cats) and the second one involving wild mammals (mongoose, fox, raccoon, wolf, jackal, badger, bat, etc.) (Kuzmin et al., 2012). Stray dogs and probably jackals in India are the main vectors or reservoirs that sustain the disease in humans and other animals through bite of the infected ones (Singh et al., 2017). Bat mediated rabies, which is most prevalent in Latin American countries, has not been reported in India. With the aim to eradicate the dog-borne rabies in humans by 2030, Global Alliance for Rabies Control (GARC), a non-profit organization in collaboration with international rabies stakeholders (WHO/OIE/FAO) and various other communities is engaged in rabies control activities. They have been working over a decade, hand-in-hand, at local, national and global levels raising awareness as well as financial support. Apart from such collective approaches, several intersectoral projects were launched in rabies endemic countries within Asia and Africa for the elimination of dog-mediated rabies that involves enhanced educational awareness and mass immunization of dogs at risk (WHO, 2015). The present review emphasizes the current status, epidemiology, prevention and control strategies of rabies especially in Indian context.

\section{Rabies virus}

Rabies virus is a, negative sense, single-stranded, enveloped, bullet shaped RNA virus of the genus Lyssavirus under the family Rhabdoviridae. Presently, 7 distinct genotypes of RABV have been found to circulate in nature. Classical rabies virus genotype 1 (street and laboratory strains) is the globally prevalent and causing disease in $>99 \%$ cases in humans as well as animals (King et al., 2011). The other 6 genotypes named as rabies- related viruses (RRVs) such like Lagos bat virus (genotype-2), Mokola bat virus (genotype-3), Duvenhage virus (genotype-4), European bat Lyssaviruses (genotypes-5 and 6), and Australian bat Lyssavirus (genotype-7), are prevalent in certain areas of Africa, Western and Eastern Europe and Australia (Gould et al., 1998; Heaton et al., 1999). The fatal classical rabies - like disease in humans as well as animals is known to be caused by all the RRVs, except Lagos bat virus. So far, the role of RRVs has been established in the death of 5 human patients (Smith, 1996). The genome of RABV contains 5 highly conserved genes in the following order from 3' leader sequence, N, NS, M, G and L (Yousaf et al., 2012). The N gene encodes a highly conserved nucleoprotein with 'group specific' antigenic determinants shared by all rabies viruses and is exploited for diagnosis and virus identification. The $G$ gene encodes trans-membrane glycoprotein, a 'serotype specific' antigen responsible for pathogenesis and induces neutralizing antibodies in the host (Singh et al., 2017).

\section{Epidemiology of rabies}

Rabies affects all warm blooded animals and incidences have been reported from all continents except Australia and Antartica (Singh et al., 2017). Asia remains the hot spot in terms of both incidences and reservoirs. In Asia, over 3 billion human beings are at the risk of canine mediated rabies and it witnesses 30000 deaths annually ( 1 death every 15 minutes). The mortality rate in children below 15 years of age is more. The South Asian region records a maximum incidence of rabies outbreak, with India and Bangladesh in the lead. Other nations in the region and its vicinity with a considerable prevalence of rabies are Nepal, Bhutan, Myanmar, Thailand and Indonesia. The prevalence across domesticated species of animals in the region is in the range of 20-50\%. In India, rabies is widely prevalent except Andaman and 
Nicobar islands (Sehgal \& Bhatia, 1985). Increasing trend in stray dog population, urbanization and the lack of environmental hygiene among the densely populated rural communities are considered as critical risk factors in the predominance of rabies in Asian as well as African countries. On the contrary, European nations zero down rabies in humans by compulsory vaccination in animals, especially in dogs (Singh et al., 2017).

The susceptibility of animals to RABV depends on several factors and there is difference in the reservoirs of disease among different geographical regions. Various studies have documented prevalence of rabies as $61.4 \%$ in cattle and buffaloes, $48.7 \%$ in goats, $48 \%$ in dogs, $45 \%$ in horses and $21.9 \%$ in cats (WHO, 2005; Sudarshan et al., 2006; Singh et al., 2017). Rabies outbreaks in domestic and wild animals in India are reported round the year with all such cases traced back to the bite of rabid dogs (Singh et al., 1990; Singh et al., 1995). According to the National Health Profile-2015, Ministry of Health and Family Welfare (MoHFW), Government of India (GOI), 104 cases has been reported from January to December, 2014 and the number showed a decline from the 132 cases of human rabies during 2013. West Bengal and Uttar Pradesh recorded maximum number of rabies outbreaks during 2014. In > 99\% cases of human rabies worldwide, rabid dog has been found as a main source of infection (WHO, 2013). Eradication efforts in endemic countries have suffered heavily from systemic deficiencies, starting with under-reporting that has hampered synergized global response by hiding its real magnitude (Singh et al., 2017). A study conducted from 11 states/union territories of India during January 2012 to December 2014 showed about $52.3 \%$ of rabies cases were from Karnataka, $18 \%$ from Maharashtra, 7.8\% from Tamil Nadu, 6.3\% from Kerala and $3.1 \%$ from Andhra Pradesh states. West Bengal was the worst affected state, with 47 rabies deaths in 2016, followed by Karnataka with 19 deaths (Mani et al., 2016).

\section{Transmission}

Rabies in human beings develops from the bites of infected animals, predominantly dogs $(91.5 \%)$ that have contracted the virus from feral or fellow infected creatures (Menezes, 2008). The transmission of virus occurs only when the saliva of the infected animal comes into contact with a broken skin or mucous membrane (Figure 1). The risk associated with the infection is reported to be high through the bite (5\%-80\%) than scratches or

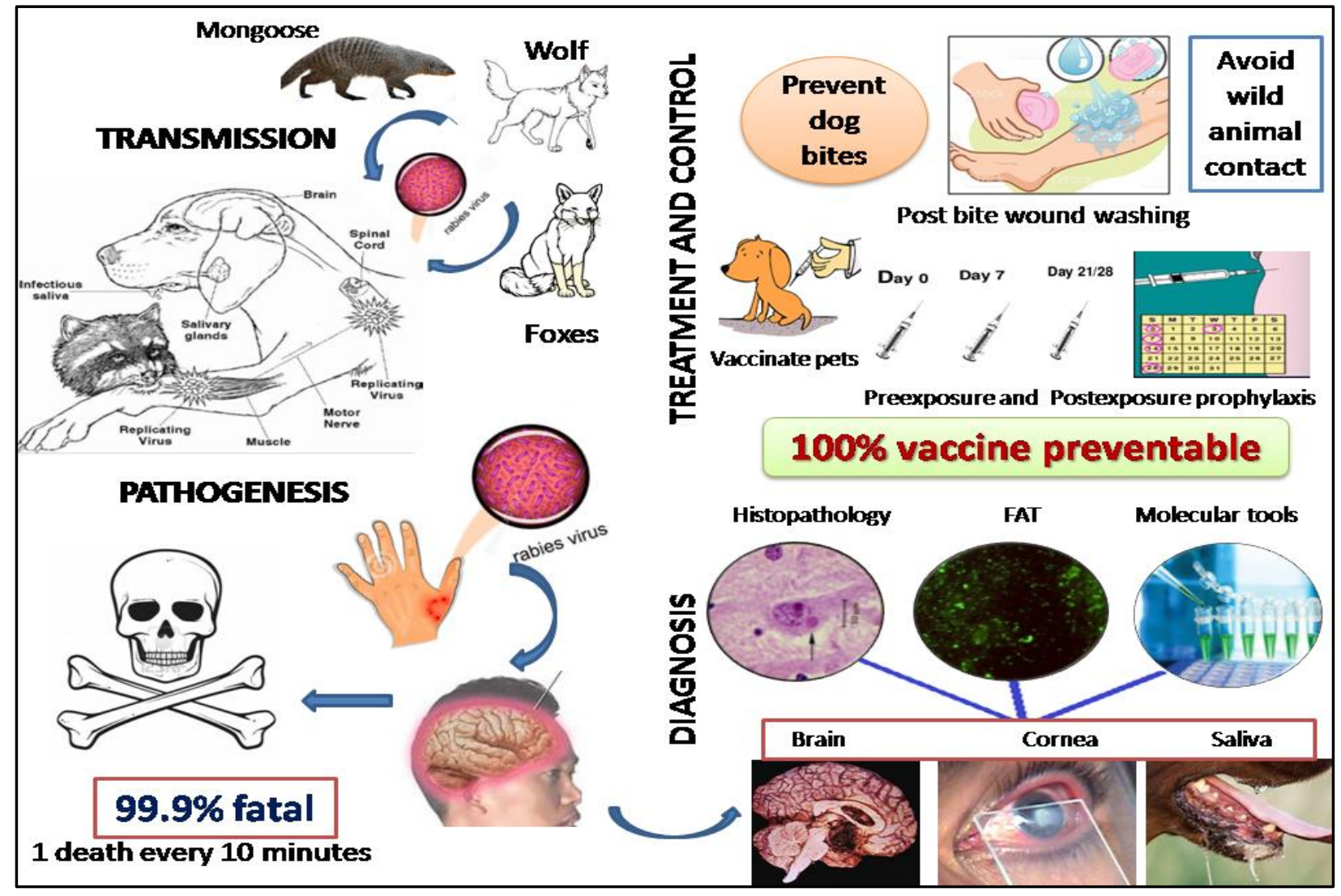

Figure 1: Transmission of rabies, diagnosis and elements of prevention and control

Journal of Experimental Biology and Agriculture Science http://www.jebas.org 
licks $(0.1 \%-1 \%)$ from the affected animal. Fatality depends on the site of bite and the quantum of virus in the saliva of bitten rabid animal (Hemachudha et al., 2013). However, disease transmission through non- bite exposures such as cornea and organ transplants and contact with the infected materials such as brain tissues have also been reported (Winkler et al., 1973; Gibbons, 2002; Hellenbrand et al. 2005; Takayama, 2005; Milton et al., 2015). Bat colonies are known wildlife reservoirs for RABV variants in northern hemispheres. Invasive activities like skinning of infected animals accompanied with improper operating procedures enhances the risk of contraction of disease. Transmission through gastro-intestinal tract has also been documented (CDC, 1999). Exposure to live attenuated vaccines during the production stage may have potential risk. The persons who are involved in capturing the animals for birth control programmes are also at potential risk because of the threat of bite and scratch. Even though birds have all along been considered to be resistant to rabies, an unusual case of natural rabies virus infection following the bite of rabid dog has been reported recently in Kerala, India (Baby et al., 2015).

\section{Pathogenesis}

Detailed pathogenesis of rabies virus has been recently reviewed by Singh et al. (2017). The sequence of events in the disease process involves: 1) replication of the virus in the peripheral tissues, 2) spread along the peripheral nerves and the spinal cord to the brain, 3) dissemination within the central nervous system (CNS) and its 4) centrifugal spread along nerves to various tissues and organs. These sequential steps have been elucidated from a number of experiments in mouse models using laboratory fixed strains (Mifune et al., 1980). Although these events may not mimic closely the natural disease process either in human or in rabies vector, yet understanding of these events is necessary for treatment and control of the disease.

\subsection{Entry of virus}

The RABV binds neurons or muscle cells through receptors on the cell surface. A critical step in the disease process of street virus which differs from fixed virus is the involvement of muscle cell and occasional fibroblast infection (Johnson, 1965; Coulon et al., 1989). The virus remains undetected at the site when it enters an eclipse phase and replicates in muscles sequestered at or near the ingress site prior to nerve entry (Murphy et al., 1973). After the variable incubation period, the uptake of virus is completely restricted to motor end plates and axons in the peripheral nervous system (PNS) through receptor mediated endocytosis without affecting the sensory and autonomic nerve endings (Ugolini, 2008). However, there is a possible chance of transmission of bat RABV variants via sensory or sympathetic skin innervation (Ugolini, 2011). Velandia-Romero et al. (2013) reported that large sensory neurons preferentially capture and passage RABV to the dorsal root ganglion after inoculation in plantar foot-pad of adult mice.

Nicotinic acetylcholine receptor (nAchR) is localized in the post synaptic membrane of motor neurons, neuromuscular junction (NMJ) on myotubes and in neurons of the CNS. Binding to $\mathrm{nAchR}$ concentrates the virus at the NMJ and aids in the uptake by nerve terminals by binding of RABV-G to micro-domains formed by another protein receptor known as neural cell adhesion molecule (NCAM)/ CD56 through gangliosides (Lafon et al., 2008). NCAM is present in cell bodies of pre-synaptic membranes of neurons of CNS as well as non-myelinated axons of the PNS. Low affinity neurotrophin receptor /p75NTR is the third protein receptor expressed at synapses of neurons (Tuffereau et al., 1998). Direct penetrating injury facilitates direct entry of virus to nerve terminals without replication in muscle (Coulon et al., 1989; Shankar et al., 1991).

\subsection{Replication of virus}

Upon getting endocytosed in the peripheral neurons, transmission of virus to the CNS occurs by fast retrograde axoplasmic flow, but drugs and neurectomy prevent spread, whereas binding with p75NTR facilitates transcytosis (Gluska et al., 2014). The virus then reaches the neurons of the CNS in dorsal root ganglia and spinal cord where it multiplies and further spread to brain. Rapid multiplication of the virus is facilitated in almost all areas of the brain, however, with minimal pathological findings. Affection of neurons in limbic areas of brain results in behavioural changes, which leads to transmission through bite of infected animals. Neuronal dysfunction rather than neuronal damage is believed to be the mechanism by which RABV causes disease (Tsiang, 1982). The possible mechanisms of neuronal dysfunction were extensively studied and described as alteration of neurotransmission (Dumrongphol et al., 1996), disturbance of ion channels (Iwata et al., 1999), degeneration of neuronal processes and synaptic structure disruption ( $\mathrm{Li}$ et al., 2005), down regulation of protein synthesis (Dhingra et al., 2007) and increased production of nitric oxide (Nakamichi et al., 2004). The possible strategy employed by the virus to favour its advancement through the nervous system is inhibition of apoptosis as there is an inverse relation between induction of apoptosis and the capacity of a RABV strain to invade brain (Thoulouze et al., 2003). By slow centrifugal anterograde axoplasmic flow, the virus moves from the CNS to muscle spindles, skin, hair follicles, salivary glands, lungs, heart muscle and abdominal visceral organs (Hemachudha et al., 2002). 


\subsection{Evasion strategies of virus}

The evasion strategy used by RABV is by inhibiting both innate and adaptive immune responses. Toll - like receptor 3 (TLR3) is an intracellular innate immune receptor in neurons (Jackson et al., 2006). In normal neurons, TLR3 is present within the endosomes in the neuronal cytoplasm; however, RABV sequesters TLR3 in Negri bodies (Menager et al., 2009). As there is lack of antigen presenting cells and lymphatic drainage, the CNS cannot induce an adaptive immune response against RABV. However, activated T cells especially CD8+ T cells and monocytes cross the intact bloodbrain barrier but undergo death (Lafon, 2008). B cells needs disruption of the barrier in order to reach brain (Hooper et al., 2009). Antibody response is elicited during the later phase of infection with a low titre in the CSF, the source of which is not clear whether; it is from the virus in the periphery or from CNS (Johnson et al., 2010). RABV adopts stealth to keep away from stimulating the neutralizing host immunity by regulating the rabies virus glycoprotein (RABV-G) expression at the infection site as well as in neural tissues during its movement towards the CNS and there is an inverse association between pathogenicity and RABV-G expression (Yan et al., 2001; Zhang et al., 2013). On contrary, Wirblich \& Schnell (2011) surmised that the RABV-G expression level plays a role in pathogenicity, but it will not attenuate a pathogenic RABV and is not a decisive dominant factor.

\section{Diagnosis of rabies}

Prompt and precise laboratory diagnosis of rabies in humans and animals is imperative for astute administration of post-exposure preventive measures (Figure 1). The clinical signs of rabies are misdiagnosed with other neurological disorders, therefore cannot be relied upon. The isolation of RABV in albino mouse, cell lines like Neuro2a/CCL 131, BHK- 21/C13, Vero and McCoy are the most dependable and consistent methods in diagnosis of rabies. The CCL 131 cell line without any adaptation is most susceptible to street RABV. The results are obtained in $18 \mathrm{~h}$ post inoculation and hence routinely preferred for isolation (Shankar, 2009). An alternative highly sensitive method is mouse inoculation test (MIT), which is also used principally in developing countries (Singh et al., 2017). Many laboratories are targeting Negri bodies in brain impressions and sections using Seller's and Mann's staining till date. Due to poor sensitivity of these tests, direct fluorescent antibody test (dFAT) is the most comprehensively recommended test for diagnosis and interpretation of rabies in fresh brain samples in animals (WHO, 2013). An indirect rapid immuno-histochemistry test (IRIT) has been established and evaluated to detect as well as differentiate RABV variants; however, it needs further evaluation by traditional microscopy. So, a direct rapid immunohistochemical test (dRIT) for detection of rabies in humans as well as animals has also been developed
(Madhusudana et al., 2012). Lateral flow technique employing immunochromatographic principle having $100 \%$ specificity and more than $88 \%$ sensitivity enabled the early diagnosis of diverse rabies virus strains (RABV species 1, 5, 6 and 7) when compared to earlier mentioned tests (Servat et al., 2012). RT-PCR-ELISA has recently been identified for the detection of RABV (AravindhBabu et al., 2014). The dFAT, having $100 \%$ sensitivity to detect virus from fresh brain tissues is used regularly by all the laboratories envisaged to diagnose rabies and confirmative diagnosis can be made within $2 \mathrm{~h}$. Moreover, the dFAT has also been found appropriate to detect rabies positive cases (100\%) even in formalin-fixed or paraffin-embedded materials (Singh et al., 2017).

Serological tests are rarely used to diagnose rabies as the infected animal or human do not survive the disease long enough to release sufficient antibodies to detect its presence in serum. Serological tests are usually employed for detection of rabies antibodies by targeting $\mathrm{G}$ and $\mathrm{N}$ proteins and are chiefly used to assess potency of various rabies vaccines (Wasniewski \& Cliquet, 2012). Serum neutralizing tests are employed for virus serotyping that requires mouse neuroblastoma cells and G-protein reactive monoclonal antibodies (mAb-Gs). The approaches currently recommended by WHO to estimate RABV neutralizing antibodies are rapid fluorescent focus inhibition test (RFFIT) and fluorescent antibody virus neutralization test (FAVN) (Cliquet et al., 1998). A minimum measurable protective antibody titre of $0.5 \mathrm{IU} / \mathrm{ml}$ represents the level of immunity in humans and animals to rabies infection (OIE, 2016). For the transport of pet dogs from countries considered infected with rabies, an international veterinary certificate must be produced indicating that the animal has not shown any signs of rabies on the day or prior to the travel and were either vaccinated or revaccinated against rabies following the standard protocol or should have undergone an antibody titration test not less than 3 months or not more than 12 months prior to the day of travel with a protective antibody titre of not less than $0.5 \mathrm{IU} / \mathrm{ml}$. RFFIT is widely used to estimate the seroconversion following preventive measures like prophylactic vaccination, and to help clinical detection of rabies in suspected cases. Diagnosis of RABV nucleic acid in the clinical samples like cerebrospinal fluid (CSF), saliva, skin biopsy and corneal impression smear by polymerase chain reaction (PCR) is documented as reliable for the ante-mortem diagnosis of rabies (Madhusudana \& Sukumaran, 2008). Other tests which are established, which are in use in WHO or World Organization for Animal Health (OIE) reference laboratories to diagnose rabies includes tests based on the detection of nucleic acid like in situ hybridization, genome sequencing, etc (Singh et al., 2017). These methods are able to detect extremely specific viral RNA molecular subunits in brain material of experimental or routine specimens. PCR based tests are established for studying viral 
pathogenesis and epidemiological analysis apart from diagnosis. Though FAT can detect RABV within $2 \mathrm{~h}$ of receiving sample, it is not sensitive with RRVs and fails in the decomposed tissues (Heaton et al., 1999). In contrast, PCR being independent on such conditions detect even few numbers of viral particles in such samples (Singh et al., 2017).

There are no diagnostic tests available to diagnose rabies in humans during pre-clinical phase, and till the rabiespathognomonic signs like hydrophobia or aerophobia are developed, the clinical diagnosis might be difficult (Chacko et al., 2016). Several tests are required for diagnosis of rabies antemortem in humans due to the variability of the virus in different samples, the timing of collection of sample, and the antibody response of the host. Clinical samples like saliva, serum, spinal fluid, and skin biopsies of hair follicles at the neck region can be included for diagnostic tests (Warrell \& Warrell, 2004). Conventional RT-PCR, Real-time PCR, Direct dot-blot enzyme immunoassay (EIA) on saliva and Polymerase chain reaction (RThnPCR) on skin biopsy (non-neural) are available with variable sensitivity and 100\% specificity (Madhusudana et al., 2004; Nagaraj et al., 2006; Dacheux et al., 2008; Chacko et al., 2016). Saliva is a sample of choice for virus isolation as well as reverse transcription polymerase chain reaction (RT-PCR). Moreover, serum and spinal fluid can be tested for antibodies against rabies virus. Skin biopsy materials are examined for rabies antigen in the cutaneous nerve endings at the base of hair follicles (Madhusudana \& Sukumaran, 2008; Dacheux et al., 2008).

\section{Vaccination approaches in control of rabies:}

Pioneering anti-rabies immunization was performed on a boy (Joseph Meister) by Louis Pasteur in late phase of 19th century. After that plenty of effective and safe, second and third generation vaccines have been developed for use in animals and humans. Currently, a number of vaccines such as recombinant rabies virus strains or rabies antigen-glycoprotein ( $\mathrm{G}$ protein), either as a component of non-pathogenic viruses, or in plants / form of DNA vaccines are being developed (Ohara et al., 2013). To stimulate the host immunity against rabies infection, normally different forms (live intact, inactivated, attenuated) or purified components of pathogens (outer coat proteins of rabies virus) with high immunogenicity are used. This generates immune response within 2 weeks. These vaccines are administered by IM or ID routes. If dog population is sufficiently $(>70 \%)$ covered by rabies vaccination, it will reduce the disease burden in humans. Currently, the rabies vaccines are accessible to prevent and control rabies in animal population (dogs, cats, wild carnivores and bats). The vaccines administered within first few days of postexposure are reported to decrease the disease by attenuating the virus considerably. Later on the 4 dose series (day 0, 3, 7 and 14) would take care. Treatment of the category III wounds (single or multiple transdermal bites or scratches, licks on broken skin; contamination of mucous membrane with saliva from licks) with rabies immunoglobulin (RIG) should be commenced as soon as possible after exposure to prevent disease development in human. In the United States alone, 11 different categories of rabies vaccines are licensed for dogs, 12 for cats, 5 for sheep, 4 for cattle, 3 for horses, and 1 for ferrets (Briggs et al., 2007).

The most challenged obstacle to develop vaccines for rabies is the need to work with the active virus, for which appropriate bio safety levels are essential. Virus like particles (VLPs) seems to be promising in this context for development of rabies vaccine. The efficacy of glycoprotein sequences of Pasteur virus (PV), Challenge Virus Standard (CVS), Evelyn- Rokitnicki-Abelseth (ERA), or street virus isolates as DNA vaccines have been evaluated. Also, the advancement in science in the recent years has made momentous progress in the design of vectors suited for gene delivery of the virus components. However, drawbacks related to poor immunogenicity and requirement of larger doses of DNA in animals remain as a fathomless issue in rabies DNA vaccination (Yang et al., 2013).

Glycoprotein expressed on the surface of the vaccinia virus, canary pox virus (Yang et al., 2013), canine adenovirus (Zhang et al. 2008), chimeric lyssavirus glycoprotein with segments from Rabies virus and Mokola virus (Badrane et al., 2001) are the recombinant vaccines which provide immunization against more than one lyssavirus. DNA vaccination with glycoprotein cloned into a plasmid vector has also been developed as vaccines against rabies.

Vaccination in wild animals is an essential part in control of rabies so as to prevent its spread to domestic animals and human. Oral Rabies Vaccine (ORV) laden baits have been successfully established for red, Arctic, and gray foxes; coyotes, raccoon dogs, raccoons, skunks, and domestic dogs (Yang et al., 2013). ORV was explicated to vaccinate free-ranging wild animals in geographically large enzootic areas, to subjugate the development and extent of a rabies epizootic, or to establish a rabies-free buffer zone (Muller et al., 2001).

Vaccination for rabies can be either pre- or post-exposure. Preexposure vaccination is performed to safeguard those who are at high risk of rabies exposure. Post-exposure vaccination is performed after the bite of rabies suspected animal to prevent the development of disease. The vaccines used for pre-exposure and post-exposure prophylaxis remains the same, but the schedule varies. Inactivated animal nerve tissue vaccines (NTV) from rabbit brain and later sheep and goat brain were used previously, but later discontinued due to the high levels of myelin that caused sensitization in some vaccine recipients and, in extreme cases, 
fatal encephalitis (Fishbein et al., 1993; Hicks et al., 2012). In India, NTV was used for post-exposure treatment, but the production was stopped in December, 2004 due to the adverse reactions. NTV was later replaced by cell culture adopted or embryonated egg passaged vaccines which were found safer and more efficient than older vaccines.

\subsection{Pre-exposure vaccination}

Pre-exposure vaccination is advisable to people at high risk of exposure like veterinarians, laboratory staff working with rabies virus, wildlife officers, animal handlers, children living in areas at risk, and individuals living in or travelling to areas of risk. The schedule of pre-exposure vaccination consists of three intramuscular $(1 \mathrm{ml})$ or intradermal (i.d.) injections $(0.1 \mathrm{ml}$ volume) of cell culture/ embryonated egg adapted vaccine on days 0,7 and 21 or 28 (WHO, 2014). The deltoid area of the arm for adults and the anterolateral area of the thigh for young children (less than 1 year of age) are preferred for administration of vaccine but, it should never be administered in the gluteal area due to lower neutralizing antibody titres (Fishbein et al., 1988). However, intradermal vaccination requires trained staff and qualified medical officer. The antibody titre of the vaccinated individuals should be tested one month after the last dose and if titre is $0.5 \mathrm{IU} / \mathrm{ml}$, booster doses are recommended (WHO, 2001). Periodic booster vaccinations are not recommended for general travellers, but if a previously vaccinated (complete series of vaccination) person gets exposed to scratch/bite from an infected animal, he must receive two booster doses of vaccine, first dose on the day of exposure and the other on the third day (WHO, 2014).

\subsection{Post-exposure prophylaxis of rabies}

In rabies endemic areas, every animal bite or history of bite or contact from a suspected rabid animal requires prompt post-exposure prophylaxis such as wound treatment and immunization depending on the location of injury with the suspected case (Table 1). Due to highly fatal nature of rabies, rabid animal bite must be considered as a "medical emergency" and "life-saving" post- exposure prophylaxis must be provided immediately. Persons who come for treatment even months after a possible rabies exposure should be considered as recent event and treated immediately (NICD, 2007; NCDC, 2015; Singh et al., 2017). The observation period for biting dogs and cats is 10 days. The natural history of rabies in mammals other than dogs or cats is not fully understood and therefore the 10-day observation period may not be applicable. The treatment may be modified if the biting animal (dog and cat) remains healthy throughout the observation period of 10 days by converting post-exposure prophylaxis to pre-exposure vaccination by skipping the vaccine dose on day 14 and administering it on day 28 while using Essen schedule. The Essen schedule (1-1-1-1-1, 5 visits) consist of 5 doses of i.m. injection of CCV on days $0,3,7,14$ and 28 for postexposure prophylaxis (NICD, 2007; NCDC, 2015; Singh et al., 2017). As rabies is $100 \%$ fatal, there is no contraindication to PEP. There are no contraindications for pregnancy, lactation, infancy, old age and concurrent illness in case of rabies exposure for PEP. Further, rabies vaccine does not have any adverse effect on pregnant woman, course of pregnancy, fetus or lactating mother. Persons taking chloroquine for malaria treatment may have a reduced response to i.d. rabies vaccination. These patients should receive the rabies vaccine intramuscularly (NICD, 2007; NCDC, 2015; Singh et al., 2017). The Milwaukee protocol, also known as Wisconsin protocol was an experimental course of treatment for rabies in human beings. The treatment involves making the patient coma by chemical induction and administration of antiviral drugs. However, medical research has reported that the Milwaukee protocol is not an effective treatment for rabies infection, so its use is not recommended (Zeiler \& Jackson, 2016). The National Centre for Disease Control (NCDC) in its expert consultation meeting in 2002, 2007 and 2013 formulated and refined the guidelines for prophylaxis of rabies to bring out uniformity in PEP (pre/post) practices. After the stoppage of nerve tissue vaccine (NTC) in 2004, the use of cell culture vaccines were recommended for PEP for economical i.d. route. For post-exposure prophylaxis, rabies immunoglobulin's derived from human or equine origin in combination with rabies vaccine is used.

Table 1 Type of contact, exposure and recommended post-exposure prophylaxis

\begin{tabular}{|c|c|c|}
\hline Category & Type of contact & $\begin{array}{l}\text { Recommended post- } \\
\text { exposure prophylaxis }\end{array}$ \\
\hline $\mathrm{I}$ & $\begin{array}{l}\text { - Touching or feeding } \\
\text { of animals } \\
\text { - Licks on intact skin } \\
\text { - Contact of intact skin } \\
\text { with secretions and } \\
\text { excretions of rabid } \\
\text { animal and human } \\
\text { case }\end{array}$ & $\begin{array}{l}\text { None, if reliable case } \\
\text { history is available }\end{array}$ \\
\hline II & $\begin{array}{l}\text { - Nibbling of } \\
\text { uncovered skin } \\
\text { - Minor scratches or } \\
\text { abrasions without } \\
\text { bleeding }\end{array}$ & $\begin{array}{l}\text { - Wound } \\
\text { management } \\
\text { - Anti-rabies } \\
\text { vaccine }\end{array}$ \\
\hline III & $\begin{array}{l}\text { - Single or multiple } \\
\text { transdermal bites or } \\
\text { scratches, licks on broken } \\
\text { skin } \\
\text { - Contamination of } \\
\text { mucous membrane } \\
\text { with saliva (i.e. licks) }\end{array}$ & $\begin{array}{l}\text { - Wound } \\
\text { management } \\
\text { - Rabies } \\
\text { immunoglobulin } \\
\text { - Anti-rabies } \\
\text { vaccine }\end{array}$ \\
\hline
\end{tabular}




\subsection{Wound treatment}

Being an enveloped virus, thorough cleansing of the wound should be carried out as soon as possible with soap/ detergent and water for $10 \mathrm{~min}$ (Singh et al., 2017). Since the RABV can persist and multiply at the site of bite for a long time, washing of wound must be done even if the patient comes late. Application of ethanol or viricidal agents such as aqueous solution of iodine or povidone dissolves the envelope of virus and hence destroys majority of virus around the wound site (Table 2). Application of irritants like oil, chilies, lime, turmeric, salt, etc are should be avoided due to its tissue damaging action. If irritants have been already applied on the wound, sufficient gentle washing with soap or detergent should be done to remove the external applicants followed by flushing with large amount of water immediately. In category III exposures, local infiltration of rabies immunoglobulin should be done in the depth and around the wound to neutralize the virus. Suturing of wound should be avoided as far as possible. If surgically unavoidable, after adequate cleansing, rabies immunoglobulin should be infiltrated in the depth and around the wound and suturing should be delayed by few hours. The delay in suturing allows diffusion of antibodies in the tissues. Minimum loose sutures should be applied for arresting the bleeding in life threatening situations. Cauterization of wound is no longer recommended as it leaves bad scar, and does not confer any additional advantage over washing the wound with water and soap. Tetanus and antibiotic prophylaxis should be given to prevent sepsis in the wound (NCDC, 2015; Singh et al., 2017).

Table 2 Management of rabid animal bite wound

\begin{tabular}{|ll|l|}
\hline $\begin{array}{l}\text { Type of wound } \\
\text { management } \\
\text { Do's }\end{array}$ & \multicolumn{1}{c|}{ Procedure } & \multicolumn{1}{c|}{ Purpose } \\
\hline Physical & $\begin{array}{l}\text { Wash with running } \\
\text { water }\end{array}$ & $\begin{array}{l}\text { Mechanical removal } \\
\text { of virus from the } \\
\text { wound }\end{array}$ \\
\hline Chemical & $\begin{array}{l}\text { - Wash the wound } \\
\text { with soap and } \\
\text { water } \\
\text { - Apply disinfectant }\end{array}$ & $\begin{array}{l}\text { Inactivation of the } \\
\text { virus }\end{array}$ \\
\hline Biological & $\begin{array}{l}\text { Infiltrate } \\
\text { immunoglobulin into } \\
\text { the depth and around } \\
\text { the wound in Category } \\
\text { III exposures }\end{array}$ \\
\hline Don'ts & $\begin{array}{l}\text { Touch the wound with bare hand } \\
\text { Apply irritants like soil, chilies, oil, lime, herbs, chalk, } \\
\text { betel leaves, etc. }\end{array}$ \\
\hline
\end{tabular}

\subsection{Passive immunization}

Anti-rabies serum or rabies immunoglobulin (RIG) provides passive immunity and had the property of binding with RABV, results neutralization of the virus. Two types of RIGs are available, namely equine rabies immunoglobulins (ERIG) and human rabies immunoglobulins (HRIG). HRIG or ERIG or $\mathrm{F}(\mathrm{ab}$ ')2 products should be used for category III as well as for some category II exposures (Table 1). Passive immunization should be started just before or shortly after administration of the first dose of vaccine in the post-exposure prophylaxis regimen by subcutaneous or intramuscularly into the gluteal region. If it is immediately unavailable, passive immunization can be administered until the 7th day after initiation of the initial series of post-exposure prophylaxis using cell culture or embryonated egg adopted rabies vaccine. ERIG is of heterologous origin raised by hyper-immunisation of horses. Presently, available ERIGs are highly purified and few adverse events have been reported. However, ERIGs should be administered after sensitivity test due to anaphylactic shock. HRIG from heterologous origin are free from side effects. HRIG should be given half the dose of ERIG because of its longer half life. RIG should be thawed to room temperature $\left(20-25^{\circ} \mathrm{C}\right)$ before use. The dose of ERIG is $40 \mathrm{IU} / \mathrm{kg}$ body weight of patient, and can be given up to 3000 IU. The ERIG produced in India contains $300 \mathrm{IU} / \mathrm{ml}$. The dose of HRIG is $20 \mathrm{IU} / \mathrm{kg}$ body weight and can be given maximum of $1500 \mathrm{IU}$. HRIG does not require any prior sensitivity testing. HRIG preparation contains $150 \mathrm{IU} / \mathrm{ml}$ (NICD, 2007; NCDC, 2015; Singh et al., 2017).

\subsection{Active immunization}

The cell culture vaccines (CCVs) like human diploid cell vaccine (HDCV), purified chick embryo cell vaccine (PCECV) and purified vero cell rabies vaccine (PVRV) are currently available in India for IM administration (Table 3). Purified duck embryo vaccine (PDEV) should always be used for post-exposure prophylaxis (PEP) by i.m. or i.d. route. Though most CCVs are marketed in freeze dried (lyophilized) form, it is recommended that these vaccines should be kept and transported at $2-8^{\circ} \mathrm{C}$ and protected from sunlight. Freezing does not damage the lyophilized vaccine but there are chances of breakage of ampoule containing the diluent. Liquid (adsorbed) rabies vaccines should never be frozen. The lyophilized vaccines should be reconstituted with the diluent provided with the vaccine immediately prior to use. Some vaccines have $0.5 \mathrm{ml}$ diluent and others have $1 \mathrm{ml}$ diluent as per the approval of the brand, which cannot be changed. For i.d. administration, the vaccine vial should be stored at $2-8^{\circ} \mathrm{C}$ after reconstitution. However reconstituted vial should be used as soon as possible and maximum within 8 hours should be used. For i.m. administration, the vaccine should be used immediately after reconstitution. In case of unforeseen delay it should not be used after 8 hours of reconstitution. The five dose regimen (days $0,3,7,14$ and 28 ) by i.m. (deltoid muscle) route, was used for 
post-exposure vaccination under the supervision of medical doctor. The sixth injection (day 90) should be considered as optional and should be given to those individuals who are immunologically deficient, old age and on steroid therapy. Higher cost of i.m. injection of CCVs is a limiting factor for its wider use. Hence during February 2006, based on recommendation of WHO, Drug Controller General of India (DCGI) approved the use of safe, efficacious and economical i.d. route of inoculation of $\mathrm{CCVs}$ by considering the results of clinical trials conducted by ICMR on safety, efficacy and feasibility. Currently, the following vaccines have been approved by DCGI for use by i.d. route. The PCECV has been marketed as Rabipur (Chiron Behring, Vaccines Pvt. Ltd) and Vaxirab N (ZydusCadila). The PVRV has been marketed as Verorab (Aventis Pasteur/Sanofi Pasteur, India Pvt. Ltd),
Pasteur Institute of India, Coonoor, Abhayrab (Human Biologicals Institute) and Indirab (Bharat BiotechInternational Ltd). Updated Thai Red Cross schedule (2-2-2-0-2) consist of administration of $0.1 \mathrm{ml}$ of reconstituted vaccine per i.d. site and two sites per visit (one on each deltoid area, an inch above the insertion of deltoid muscle) on days $0,3,7$ and 28 . The day 0 is the date of first dose administration of anti-rabies vaccine and may not be the date of rabies exposure or animal bite (NICD, 2007; NCDC, 2015; Singh et al., 2017; Diksha et al., 2018). The Zagreb regimen (2-1-1 or 2$0-1-0-1, \quad 3$ visit), an abbreviated i.m. schedule for rabies vaccination, and developed Zagreb Institute of Public Health in Croatia in 1980s. The schedule was recommended by WHO as one of the i.m. schedules for rabies vaccination in 2010. One dose is given in the right arm and one dose in the left arm at day 0 , and

Table 3 Rabies vaccines available in India

\begin{tabular}{|c|c|c|c|c|}
\hline Brand Name & Manufacturing company & Presentation & Strength & Volume \\
\hline Abhayrab & \multirow{2}{*}{ Human Biological Institute } & \multirow{2}{*}{ Injection } & $2.5 \mathrm{IU} \times 0.5 \mathrm{ml}$ & $1 \mathrm{ml}$ \\
\hline Abhayrig & & & $300 \mathrm{IU} x 1 \mathrm{ml}$ & $5 \mathrm{ml}$ \\
\hline \multirow{2}{*}{ BerirabP } & \multirow{2}{*}{ Zydus (Biogen) } & \multirow{2}{*}{ Injection } & $300 \mathrm{IU} / 2 \mathrm{ml}$ & $2 \mathrm{ml}$ \\
\hline & & & $750 \mathrm{IU} / 5 \mathrm{ml}$ & $5 \mathrm{ml}$ \\
\hline Carig & Cadila & Injection & $\begin{array}{l}\text { Rabies Immunoglobulin } 1500 \\
\text { IU, Glycine } 62.5 \mathrm{mg} \text {, Sodium } \\
\text { chloride } 45 \mathrm{mg} \text {, phenol } 0.25 \%\end{array}$ & $5 \mathrm{ml}$ \\
\hline Equirab & \multirow{2}{*}{$\begin{array}{c}\text { Bharat Serum \& Vaccines } \\
\text { Ltd }\end{array}$} & \multirow{2}{*}{ Injection } & $300 \mathrm{IU} / \mathrm{ml}$ & $5 \mathrm{ml}$ \\
\hline Rabglob & & & $150 \mathrm{IU} \times 1 \mathrm{ml}$ & $2 \mathrm{ml}$ \\
\hline Erig & \multirow{2}{*}{ Cadila (Newgen) } & \multirow{2}{*}{ Injection } & $1000 \mathrm{IU} / \mathrm{ml}$ & $5 \mathrm{ml}$ \\
\hline Hrig & & & - & $2 \mathrm{ml}$ \\
\hline Favirab & \multirow{2}{*}{ Ranbaxy } & \multirow{2}{*}{ Injection } & $200-400 \mathrm{IU}$ & $5 \mathrm{ml}$ \\
\hline Imogam Rabies & & & $300 \mathrm{IU}$ & $2 \mathrm{ml}$ \\
\hline $\begin{array}{l}\text { Rabies Vaccine } \\
\text { (HDC) }\end{array}$ & $\begin{array}{l}\text { Serum Institute of India } \\
\text { Limited }\end{array}$ & Injection & $2.5 \mathrm{IU} \times 1 \mathrm{ml}$ & $1 \mathrm{ml}$ \\
\hline Imorab & \multirow{2}{*}{ Aventis Pasteur } & \multirow{2}{*}{ Injection } & $1000 \mathrm{IU} \times 5 \mathrm{ml}$ & $5 \mathrm{ml}$ \\
\hline Imovax Rabies & & & $2.5 \mathrm{IU}$ & $1 \mathrm{ml}$ \\
\hline Pars & \multirow[b]{2}{*}{$\begin{array}{l}\text { Cadila Healthcare (Zydus } \\
\text { Cadila Healthcare Ltd) }\end{array}$} & \multirow[b]{2}{*}{ Injection } & $1000 \mathrm{IU}$ & $5 \mathrm{ml}$ \\
\hline $\begin{array}{c}\text { Pasteur Antirabies } \\
\text { Serum }\end{array}$ & & & $1000 \mathrm{IU}$ & $1 \mathrm{ml}$ \\
\hline $\begin{array}{l}\text { Rabies Vaccine } \\
\text { (Human) }\end{array}$ & Haffkine & Injection & $\begin{array}{l}\text { Rabies vaccine } 5 \% \text { w/v sheep } \\
\text { brain susp with antigenic value } \\
\text { equal to or more than } 0.3 \text {. }\end{array}$ & $30 \mathrm{ml}$ \\
\hline Rabipur & Novartis India & Injection & $2.5 \mathrm{IU}$ & $1 \mathrm{ml}$ \\
\hline \multirow{2}{*}{ Rabivax } & \multirow{2}{*}{$\begin{array}{l}\text { Serum Institute of India } \\
\text { Limited }\end{array}$} & \multirow{2}{*}{ Injection } & - & $1 \mathrm{ml}$ \\
\hline & & & $25 \mathrm{IU} \times 1 \mathrm{ml}$ & $1 \mathrm{ml}$ \\
\hline Vaxirab & Zydus (Biogen) & Injection & - & $1 \mathrm{ml}$ \\
\hline Verovax R & Human Biological Institute & Injection & - & $0.5 \mathrm{ml}$ \\
\hline Worab & Novartis India Ltd & Injection & - & $0.5 \mathrm{ml}$ \\
\hline Verorab & $\begin{array}{l}\text { Serum Institute of India } \\
\text { Limited }\end{array}$ & Injection & $2.5 \mathrm{IU}$ & - \\
\hline
\end{tabular}

Journal of Experimental Biology and Agriculture Science http://www.jebas.org 
one dose applied in the deltoid muscle on days 7 and 21 . When compared to Essen schedule, Zagreb has higher compliance, less doses, lower medical cost, better immunogenicity at an early stage and does not include administration of RIG. Recently, Zagreb regimen has been widely adopted in China, Bangladesh and Indonesia (NICD, 2007; Ren et al., 2015).

\section{Rabies research centres in India}

The diagnosis of rabies in clinical and morbid samples of animals and human in India is being executed by the CADRAD, ICARIVRI, Bareilly; ICAR-NIVEDI, Bengaluru; Guru Angad Dev Veterinary and Animal Sciences University (GADVASU), Ludhiana; NIMHANS (human samples), Bangalore; National Centre Disease control (NCDC), formerly National Institute of Communicable Disease (NICD), New Delhi and other labs, using dFAT and RT-PCR / nested PCR tests. The GADVASU also developed tests like immunohistochemistry for diagnosis of rabies in clinical samples (hair follicles, saliva, mucosal impression smears, skin) of infected animals (Singh, 2008; Singh \& Sandhu, 2008; Sandhu et al., 2011; Bansal et al., 2012).

The NIMHANS (human rabies) and NCDC (human and animal rabies) are the two World Health Organization (WHO) collaborating centres for rabies epidemiology and reference and research in rabies, respectively. The, WHO recognized tissue culture laboratory at NCDC, has been doing rabies epidemiology studies for SEAR countries since 1985. In NCDC, the ongoing research to estimate the prevalence of rabies infection in dog population in Delhi, epidemiological investigation on rabies in humans as well as animals for enactment of rabies control throughout the country and to determine the titre of rabies neutralizing antibodies in sera of man and animals by counter immunoelectrophoresis (CIE), ELISA and mouse neutralization test are being conducted.

The Central Research Institute, Kasauli was established in 1905 by Dr. David Sample. As early as in 1911, Sir David Semple pioneered in the production of neural tissue vaccine against rabies. Thereafter, anti-rabies serum production was started in 1955 and BPL inactivated rabies vaccine started in 1972 from the Institute. The rabies diagnostic work for humans and animals is being done here using dFAT, biological test, and pre- and post-exposure antibodies testing by SVNT. Preparation of diagnostic reagents such as Challenge Virus Standard (CVS), FITC conjugate (liquid and freeze dried), stains for Negri bodies, preparation of brain suspensions from normal mouse and mouse brains infected with rabies.

The American Public Health Association (APHA), in collaboration with the OIE Reference Laboratory at the CDC in Atlanta, USA, awarded three year OIE Laboratory Twinning
Project at the Veterinary College, Karnataka (KVAFSU) in Bangalore, India, to enhance capability in diagnosing animal rabies wherein collaboration with the Commonwealth Veterinary Association and the Biotechnology Company Crucell, Holland, has established a dedicated laboratory for rabies diagnosis. The objective of this lab is to increase knowledge and preparedness for control and prevention of rabies in India through sharing information, transferring technology and the provision of management skills to harmonizes methods for diagnosis of rabies as per OIE standards in Indian scenario and to ensure an expanded network of OIE reference laboratories by establishing an OIE Reference Laboratory for rabies thereby to act as a focal point by providing technical support to other laboratories for regional rabies control in the Indian subcontinent and neighbouring countries (Rahman, 2011)

\section{Rabies Research carried out in India}

The entire rabies researches mainly in animal component, so far carried out in India were tabulated with timeline and appropriate references (Table 4). At ICAR-IVRI, apart from identification of rabies in animals from clinical and post-mortem samples and studies on molecular diagnosis from stored brain tissues (Verma, 2012), molecular characterization of virus isolates from diverse species of animals and humans was also initiated by partial sequencing of $\mathrm{N}$ gene (Reddy et al., 2011), $\mathrm{P}$ gene and complete $\mathrm{G}$ gene (Cherian et al., 2015). These studied have demonstrated that all rabies virus isolates found in India are closely linked genetically with arctic-like 1a lineage viruses. However, two distinct clusters were ascertained viz., India South and India North and all the isolates shared $95.5-100 \%$ homology geographically, but not via host species (Cherian et al., 2015). A variety of molecular tests have been attempted for the efficient diagnosis of rabies in different laboratories of India. A single-tube reverse transcription polymerase chain reaction (RT-PCR) for rapid detection of rabies virus utilizing a single buffer system amplifying two primer sets of rabies nucleoprotein (533 bp) and glycoprotein (406 bp) was developed. The results of RT-PCR were correlated with the results from mouse inoculation test (MIT) and the test was found as specific as MIT (Gupta et al., 2001). An alternate approach, namely FAT, for in-process quality control of rabies vaccine against MIT was suggested and the developed rapid fluorescent focus inhibition test (RFFIT) was efficient as mouse neutralization test to check the potency of rabies vaccine (Kumar et al., 2014). Gupta et al. (2005a) developed a recombinant DNA vaccine expressing a glycoprotein, CVS-N2B, of RABV in mammalian vector and found complete protection on administration of CVS intracerebrally in mouse model. The protective antibody titer was detectable through ELISA and VNT, in experimental dogs. The immunogenicity and antigenicity of a recombinant soluble glycoprotein of rabies virus, 
produced by deleting 60 amino acid C-terminal transmembrane and cytoplasmic domains of glycoprotein from full-length glycoprotein and thereafter fusing with polyhistidine tag, transfected in Madin Darby bovine kidney (MDBK) cells and purified by $\mathrm{Ni}$-agarose affinity chromatography was assessed. The protein was found to induce immune response when injected in rabbits and also produce anti-glycoprotein antibodies antigen in immunized animal. The results of the study were promising to use recombinant soluble glycoprotein as a diagnostic antigen in ELISA (Gupta et al., 2005b).

Since no therapy is available after the clinical expression of rabies, a few studies were conducted at CADRAD, ICAR-IVRI wherein efforts were made to prevent virus replication by using various chemicals like siRNA, exogenous RIG with LPS, which showed increased survivability in mouse model against CVS-18 (Shankumar, 2010; Reddy, 2010; Reddy et al., 2011; Kushwaha, 2011). Further, role of inducible nitric oxide synthase (iNOS) and MEK-ERK1/2-MAP kinase signaling pathway inhibition in pathogenesis of rabies in mouse model has been studied (Madhu et al., 2016a; Madhu et al., 2016b; Manjunatha et al., 2017). Upon treatment with specific inhibitor of MEK1/2 in mouse model infected with rabies virus, disease development and clinical signs are delayed, survival time is increased and with reduced mortality than untreated mice (Manjunatha et al., 2017). Aminoguanidine (AG), an inhibitor of nitric oxide was also reported to reduce the disease process and increase the survival time in mouse model challenged with rabies virus by increasing CD4+, CD8+T lymphocytes. The reduction in disease process was characterised by decreased expression of TNF- $\alpha$, caspase-1, FasL and TLR-3 mRNA expression suggesting that increase in NO levels in rabies virus infection possibly contributed to development of disease through inflammation, apoptosis and immune-evasive mechanisms (Madhu et al., 2016b). Recently, a study has been undertaken to elucidate the role of TLR-3 in pathogenesis of rabies, formation of Negri bodies (Shivasharanappa, 2008; Shivasharanappa et al., 2011) and therapeutic potential by blocking TLR-3/dsRNA interaction in mouse model, which showed that blocking of TLR-3/dsRNA interaction may not block Negri body formation (Sumit, 2017). Regarding vaccine studies, several attempts were made to study different vaccine candidates and its immune response.

A Sindbis virus replicon-based DNA vaccine against rabies virus glycoprotein (G) was developed and it induced both humoral and cell mediated immune responses in mice better than conventional rabies DNA vaccine and the test vaccine was as effective as Rabipur vaccine upon challenge with CVS strain in mice (Saxena et al., 2008). Similarly, Saxena et al. (2008) simultaneously developed RNA vaccine encoding rabies virus glycoprotein gene using Sindbis virus RNA replicon and mice were immunized with Sin-Rab-G RNA and the immune responses were found similar to rabies DNA vaccine in inducing cellular and humoral responses. On challenge with rabies virus CVS strain, rabies RNA vaccine conferred protection similar to rabies DNA vaccine. These results demonstrated that replicon-based self-replicating rabies RNA vaccine with $10 \mathrm{mg}$ dose was effective in inducing immune responses and protection similar to rabies DNA vaccine. The efficacy of poly(lactide-co-glycolide) (PLG) microspheres as an oral delivery system of inactivated concentrated rabies virus (CRV) was investigated and was found to produce a significantly $(\mathrm{p}<0.001)$ higher protective antibody titer against rabies in mice group treated with PLG+ CRV than CRV alone. The survival rates of mice group treated with PLG+ CRV and CRV alone were $75 \%$ and $50 \%$, respectively, though intraperitoneally immunized groups showed $100 \%$ protection (Ramya et al., 2009). Recombinant adenoviral vectors ( $\mathrm{rAdV}$ ) encoding siRNAs against rabies virus $(\mathrm{RABV})$ polymerase $(\mathrm{L})$ and nucleoprotein $(\mathrm{N})$ genes were developed to assess its antiviral prospective against rabies. The multiplication of RABV in BHK-21 cells was inhibited after treating with vector mediated siRNA targeting both RABV-L and RABV-N gene and, the former was found more effective. Furthermore, RABV multiplication was inhibited and partial protection was observed against lethal challenge of RABV in mice treated with same vector (Sonwane et al., 2012).

\section{Control programmes initiated in India}

The WHO Collaborating Centres for Reference and Research in Rabies (NIMHANS), Centre for Rabies Epidemiology (NCDC) and Research on Rabies Pathogenesis and Prevention (Queen Saovabha Memorial Institute, Bangkok, Thailand) are working for control of rabies in SEAR region.

Food and Agriculture Organization (FAO) is instrumental in global eradication of rabies. The documents prepared by global rabies experts of FAO are "The Blueprint for Rabies Prevention and Control", "Canine Rabies blueprint" and "Blueprint for Fox Rabies Prevention and Control" to prevent human rabies by abolishing animal rabies within their borders, where rabies is present. The "Rabies Surveillance Blueprint" has been established by FAO to serve as a guideline for countries that would like to improve surveillance for rabies in any species. The OIE, being an intergovernmental organisation is instrumental in providing science-based standards, strategies and recommendations for the diagnosis, control and prevention of rabies and the production of highly efficient veterinary vaccines. The OIE ensures transparency through its global network of more than 320 reference laboratories and collaborating centres and 181 member countries to report outbreak of cases, gathering of scientific information from its worldwide reference laboratories and thus encourages governments and international investors in rabies control programmes. In 2012, OIE has created an antirabies vaccine bank for dogs and providing to countries for rabies 
Table 4 Rabies research carried out in India over the timeline.

\begin{tabular}{|c|c|c|c|}
\hline S. No & Timeline & Salient research findings & References \\
\hline 1. & 2018 & $\begin{array}{l}\text { Rabies virus in animals and humans showed temporally and spatially stable during } \\
2004-2014 \text { in Punjab, India. Dog cases were more during March and August months. } \\
\text { Monthly case numbers in buffalo decreased over time. Time-series models revealed that } \\
\text { buffalo cases were spill over from dogs. }\end{array}$ & Brookes et al. (2018) \\
\hline 2. & 2017 & $\begin{array}{l}\text { Inhibition of MEK-ERK1/2-MAP kinase signalling pathway reduces rabies virus } \\
\text { induced pathologies in mouse model. }\end{array}$ & $\begin{array}{l}\text { Manjunatha et al. } \\
\text { (2017) }\end{array}$ \\
\hline 3. & 2017 & $\begin{array}{l}\text { Sequencing of partial } \mathrm{N} \text { gene of RABV from Gujarat state showed Indian RABV } \\
\text { isolates cluster under Arctic like lineage of Genotype } 1 .\end{array}$ & $\begin{array}{l}\text { Vagheshwari et al. } \\
\text { (2017) }\end{array}$ \\
\hline 4. & 2016 & $\begin{array}{l}\text { Inhibition of iNOS by AG administration led to decreased expression of TNF- } \alpha \text {, } \\
\text { caspase-1, FasL and TLR-3 mRNA levels suggesting that increased NO levels in RABV } \\
\text { infection possibly contributed to development of disease through inflammation, } \\
\text { apoptosis and immune-evasive mechanisms. }\end{array}$ & Madhu et al. (2016b) \\
\hline 5. & 2016 & $\begin{array}{l}\text { Nitric oxide played significant role in the regulation of immune responses during } \\
\text { RABV infection in mice. }\end{array}$ & Madhu et al. (2016a) \\
\hline 6. & 2015 & $\begin{array}{l}\text { Immunochromatographic diagnostic test kit was developed for diagnosis of rabies in } \\
\text { field conditions. Sensitivity of the kit was found to be } 91.66 \% \text {, specificity } 100 \% \text { and } \\
\text { accuracy was } 94.11 \% \text {. }\end{array}$ & Sharma et al. (2015) \\
\hline 7. & 2015 & $\begin{array}{l}\text { Vaccinate-assess-move method of mass canine rabies vaccination was done using } \\
\text { mobile technology data collection in Ranchi, India. }\end{array}$ & Gibson et al. (2015) \\
\hline 8. & 2015 & $\begin{array}{l}\text { Various factors like age, sex, breed and vaccine brands have no significant effect on the } \\
\text { protective anti-rabies antibody titres. }\end{array}$ & $\begin{array}{l}\text { Savaliya et al. } \\
\quad \text { (2015) }\end{array}$ \\
\hline 9. & 2015 & $\begin{array}{l}\text { Naturally acquired rabies infection in a bird, Gallus domesticus was reported for the } \\
\text { first time in India. The disease was identified from highly endemic canine rabies areas. } \\
\text { It indicates that spill over of infection even to an unusual host is possible in highly } \\
\text { endemic areas. }\end{array}$ & Baby et al. (2015) \\
\hline 10. & 2015 & $\begin{array}{l}\text { Phylogenetic analysis targeting the complete G gene revealed that all Indian RABV } \\
\text { isolates are genetically closely related with Arctic-like 1a lineage viruses. However, two } \\
\text { distinct clusters were identified namely, India South and India North. All the Indian } \\
\text { rabies isolates had } 95.5-100 \% \text { homology related to geography, but not to host species. }\end{array}$ & Cherian et al. (2015) \\
\hline 11. & 2015 & $\begin{array}{l}\text { CVS- } 11 \text { strain of RABV was adapted in BHK- } 21 \text { cells had vaccine candidate potential } \\
\text { and suitable for use in rapid fluorescent focus inhibition test. }\end{array}$ & Patel et al. (2015) \\
\hline 12. & 2014 & $\begin{array}{l}\text { Vaxirab-N developed by Zydus Cadila was found to be safe and immunogenic by both } \\
\text { intramuscular and intradermal route and is recommended for rabies prophylaxis }\end{array}$ & $\begin{array}{l}\text { Ashwath Narayana } \\
\text { et al. (2014) }\end{array}$ \\
\hline 13. & 2014 & $\begin{array}{l}\text { A rapid field test latex agglutination test (LAT) was developed for measuring RABV } \\
\text { antibodies using recombinant glycoprotein expressed in an insect cell system. }\end{array}$ & Jemima et al. (2014) \\
\hline 14. & 2014 & $\begin{array}{l}\text { The antiviral potential of small interfering RNAs (siRNAs) targeting RABV polymerase } \\
\text { (L) and nucleoprotein }(\mathrm{N}) \text { genes was investigated. siRNA targeting RABV N inhibits } \\
\text { multiplication and conferred protection in mice against lethal RABV challenge. }\end{array}$ & Singh et al. (2014) \\
\hline
\end{tabular}




\section{S. No Timeline}

15. siRNAs targeting RABV G and N genes were evaluated as antiviral agents against

15. 2013 RABV in vitro in BHK-21 cells. The anti-rabies-virus effect was observed as $87.4 \%$ reduction in the release of $\mathrm{RABV}$.

Meshram et al. (2013)

\begin{tabular}{|l}
\hline $2013 \quad \begin{array}{l}\text { TaqMan real time PCR can serve as more sensitive and viable approach for the } \\
\text { intravitam diagnosis of rabies as compared to Nested RT-PCR for detection of rabies } \\
\text { from urine of suspected animals. }\end{array}$
\end{tabular}

Dandale et al. (2013) from urine of suspected animals.

\begin{tabular}{|cclll}
\hline 17. & 2012 & $\begin{array}{l}\text { Adenoviral vector mediated siRNA inhibited RABV multiplication in vitro in BHK-21 } \\
\text { cells. siRNA targeting RABV L gene was comparatively more efficient than targeting } \\
\text { RABV N gene. In vivo studies in mice inhibited RABV multiplication in mice and } \\
\text { imparted partial protection against lethal rabies. }\end{array}$ & $\begin{array}{c}\text { Sonwane et al. } \\
\text { (2012) }\end{array}$ \\
\hline 18. & 2012 & $\begin{array}{l}\text { TaqMan real time PCR is a useful, specific, sensitive and better molecular approach for } \\
\text { antemortem rabies diagnosis from skin samples of rabies suspected animals. }\end{array}$ & Bansal et al. (2012) \\
\hline 19. & 2012 & $\begin{array}{l}\text { Adenovirus expressing siRNA against RABV-N gene inhibited the RABV } \\
\text { multiplication both, in vitro and in vivo and conferred significant protection against } \\
\text { lethal RABV challenge. }\end{array}$ & Gupta et al. (2012) \\
\hline 20. & 2012 & $\begin{array}{l}\text { Rapid sensitive and specific RT-PCR assay for routine laboratory diagnosis of rabies in } \\
\text { postmortem brain samples from different species of animals was evaluated. }\end{array}$ & $\begin{array}{c}\text { Aravindh Babu et al. } \\
(2012)\end{array}$
\end{tabular}

\begin{tabular}{|c|c|c|c|}
\hline 21. & 2011 & $\begin{array}{l}\text { Protective antirabies antibody titre was found only in } 1 \% \text { of the street dogs and } 16 \% \text { of } \\
\text { the pet dogs in Chandigarh, India. The awareness among the pet dog owners about the } \\
\text { antirabies vaccination schedule was low as } 18 \% \text { did not know the vaccination status of } \\
\text { the dog and } 66 \% \text { had got the initial immunization done with only three doses and annual } \\
\text { boosters were not given. }\end{array}$ & Singh et al. (2011) \\
\hline
\end{tabular}

\begin{tabular}{|lll}
\hline 22. & $\begin{array}{l}\text { Phylogenetic analysis of partial N gene sequences of RABV from cows with paralytic } \\
\text { rabies and } 11 \text { southern Indian isolates showed close relatedness to Sri Lankan RABV } \\
\text { lineage. }\end{array}$ & $\begin{array}{c}\text { Aravindhbabu et al. } \\
\text { (2011) }\end{array}$
\end{tabular}

\begin{tabular}{|l} 
The N gene-based phylogenetic analysis indicated that all Indian RABV isolates are \\
\hline 23. $2011 \quad \begin{array}{l}\text { genetically closely related with a single cluster under arctic/arctic-like viruses. } \\
\text { However, two distinct clusters were realized in P gene-based phylogeny viz., RABV } \\
\text { isolates of Punjab and RABV isolates of remaining parts of India. All the Indian RABV } \\
\text { isolates were closely related to geography (>95\% homology), but not to host species. }\end{array}$
\end{tabular}

$2011 \quad \begin{aligned} & \text { Nested RT-PCR can be used for diagnosis of rabies in brain and skin samples of } \\ & \text { suspected animals. }\end{aligned}$

\begin{tabular}{|c|c|c|}
\hline 25. & 2011 & $\begin{array}{l}\text { IHC was more efficient and precise technique for detecting RABV antigen or Negri } \\
\text { bodies in paraffin embedded formalin fixed tissues from rabies suspected case than } \\
\text { conventional H\&E staining. }\end{array}$ \\
\hline 26. & 2009 & $\begin{array}{l}\text { Sequence analysis of nucleoprotein gene of } 22 \mathrm{RABV} \text { isolates from domestic animals in } \\
\text { Southern India during 2004-2005 showed that RABV isolates belong to genotype } 1 \text {. }\end{array}$ \\
\hline 27. & 2009 & $\begin{array}{l}\text { SINV replicon-based DNA vaccine encoding RABV G was capable of inducing the } \\
\text { protective level of specific immune response in dogs. }\end{array}$ \\
\hline 28. & 2009 & $\begin{array}{l}\text { Replicon-based self-replicating rabies RNA vaccine encoding G gene with } 10 \mu \mathrm{g} \text { dose } \\
\text { was effective in inducing immune responses and protection. }\end{array}$ \\
\hline
\end{tabular}

Kaw et al. (2011)

Reddy et al. (2011) 


\begin{tabular}{|c|c|c|c|}
\hline S. No & Timeline & Salient research findings & References \\
\hline 30. & 2008 & $\begin{array}{l}\text { A five year study (1995-1999) in Northern India showed } 56 \% \text { of domestic animals were } \\
\text { positive for rabies by FAT, MIT and histopathology. Variations in clinical signs were } \\
\text { observed between dogs and bovines. Rabies incidence was highest among adult male } \\
\text { dogs and seasonal pattern with more rabies cases during January to April, and August to } \\
\text { November months. Accumulated history records revealed that } 78 \% \text { of owned rabid dogs } \\
\text { were not prophylactically vaccinated against rabies. }\end{array}$ & $\begin{array}{l}\text { Singh \& Sandhu } \\
\quad(2008)\end{array}$ \\
\hline 31. & 2008 & $\begin{array}{l}\text { A rabies post-exposure prophylaxis study was carried out to examine the efficacy of two } \\
\text { commercially available rabies vaccines Nobivac Rabies (Intervet) and Rabisin (Merial), } \\
\text { and the efficacy of a } 5 \text { - or } 3 \text {-dose vaccination regime. Both vaccines were found to be } \\
\text { safe and effective in preventing rabies when inoculated intramuscularly applying the } 5 \text { - } \\
\text { dose regime }(0,3,7,14 \text { and } 28 \text { days). By } 3 \text {-dose regime }(0,5 \text { and } 28 \text { days) Nobivac } \\
\text { rabies was also found to be safe and effective in preventing rabies. }\end{array}$ & $\begin{array}{l}\text { Manickama et al. } \\
\qquad(2008)\end{array}$ \\
\hline 32. & 2008 & $\begin{array}{l}\text { A pilot rabies control programme was launched in five Indian federal states in February, } \\
2007 \text {. This initiative was led by the Animal Welfare Board of India (AWBI) federating } \\
\text { many animal welfare organizations and the Ministry of Agriculture. Its aim was creating } \\
\text { a "Rabies Free India". The programme combines parenteral vaccination of accessible } \\
\text { owned and stray dogs, spaying/neutering followed by parenteral vaccination and oral } \\
\text { vaccination of inaccessible dogs. The freeze-dried vaccine SAG2, including the bait } \\
\text { casing, was tested under both experimental and field conditions. }\end{array}$ & $\begin{array}{l}\text { Pradhan et al. } \\
\qquad(2008)\end{array}$ \\
\hline 33. & 2008 & $\begin{array}{l}\text { A sindbis virus (SINV) replicon-based DNA vaccine encoding RABV G was developed } \\
\text { and effective in inducing both humoral and cellular immune responses and can be } \\
\text { considered as effective vaccine against rabies. }\end{array}$ & Saxena et al. (2008) \\
\hline 34. & 2007 & $\begin{array}{l}\text { A bicistronic DNA vaccine was developed for dogs to induce virus neutralizing immune } \\
\text { responses against rabies glycoprotein and canine parvovirus (CPV) VP2 genes. }\end{array}$ & Patial et al. (2007) \\
\hline 35. & 2007 & $\begin{array}{l}\text { Humoral immune response was studied in dogs vaccinated with different tissue culture } \\
\text { vaccines commonly used for immunization of dogs in India. The results revealed that } \\
\text { after single dose of vaccination only } 56 \% \text { dogs developed protective titer. The response } \\
\text { of the three vaccines used in the study was not similar, highlighting the need to maintain } \\
\text { post marketing surveillance. }\end{array}$ & Singh et al. (2007) \\
\hline 36. & 2007 & $\begin{array}{l}\text { Safety, immunogenicity and efficacy of Rabidog SAG2 bait were evaluated in Indian } \\
\text { stray dogs in captivity. Safety was demonstrated by absence of clinical signs, salivary } \\
\text { excretion and absence of replication of vaccine strain in brain and salivary glands. }\end{array}$ & Cliquet et al. (2007) \\
\hline 37. & 2007 & $\begin{array}{l}\text { Histopathological alterations in brains of rabies infected buffaloes and cattle has been } \\
\text { described }\end{array}$ & $\begin{array}{l}\text { Jamadagni et al. } \\
\qquad \text { (2007) }\end{array}$ \\
\hline 38. & 2006 & $\begin{array}{l}\text { Cytoplasmic domain of } \mathrm{G} \text { gene, noncoding G-L intergenic region and polymerase gene } \\
\text { nucleotide sequence analysis of } 29 \mathrm{RABV} \text { isolates of different species of animals from } \\
\text { four states revealed that RABV isolates belong to genotype } 1 \text { and related to } \\
\text { geographically but not related to host species. Analysis of the data indicated that dog } \\
\text { RABV variants are the major circulating viruses in India that transmit the disease to other } \\
\text { domestic animals and humans. }\end{array}$ & $\begin{array}{l}\text { Nagarajan et al. } \\
\text { (2006) }\end{array}$ \\
\hline 39. & 2006 & $\begin{array}{l}\text { Flow cytometry could be used to detect RABV antigen in infected cells and to predict } \\
\text { serum antibody titres. }\end{array}$ & $\begin{array}{l}\text { Vengatesan et al. } \\
\qquad(2006)\end{array}$ \\
\hline 40. & 2004 & $\begin{array}{l}\text { Simple enzyme immuno-assay (EIA) was developed to detect rabies antigen in the brain } \\
\text { specimens of animals and humans. The concordance between FAT and EIA was } 98.4 \% \\
\text { with brain samples, } 83.3 \% \text { with saliva and } 91.6 \% \text { with CSF. The specificity of the test } \\
\text { was found to be } 100 \% \text {. }\end{array}$ & $\begin{array}{l}\text { Vasanth et al. } \\
\quad(2004)\end{array}$ \\
\hline
\end{tabular}




\begin{tabular}{|c|c|c|c|}
\hline S. No & Timeline & Salient research findings & References \\
\hline 40. & 2004 & $\begin{array}{l}\text { Dot blot enzyme immunoassay (DIA) test was developed for the post-mortem diagnosis } \\
\text { of rabies in animals and humans. The concordance between FAT and DIA was } 98.4 \% \\
\text { in brain, } 83.3 \% \text { in saliva and } 91.6 \% \text { in CSF samples. The specificity of the test was } \\
\text { found to be } 100 \% \text {. }\end{array}$ & $\begin{array}{l}\text { Madhusudana et al. } \\
\text { (2004) }\end{array}$ \\
\hline 41. & 2001 & $\begin{array}{l}\text { A simple method for the rapid detection of RABV was developed by employing a } \\
\text { single-tube, non-interrupted RT-PCR in brain tissue. }\end{array}$ & Gupta et al. (2001) \\
\hline 42. & 1996 & $\begin{array}{l}\text { Avidin-biotin dot ELISA test was standardized to detect rabies viral antigens from brain } \\
\text { of animals. No significant difference was observed between FAT and avidin-biotin dot } \\
\text { ELISA. }\end{array}$ & $\begin{array}{l}\text { Jayakumar et al. } \\
\qquad(1996)\end{array}$ \\
\hline 43. & 1995 & $\begin{array}{l}\text { Rapid, simple and economical field test Dot ELISA was developed for visual detection } \\
\text { of rabies antigen in animals. Dot ELISA was compared with FAT and the concordance } \\
\text { between the two tests was } 95.25 \% \text {. }\end{array}$ & $\begin{array}{l}\text { Jayakumar et al. } \\
\qquad(1995)\end{array}$ \\
\hline 44. & 1994 & $\begin{array}{l}\text { A dipstick dot enzyme immuno diagnosis test was standardized to detect rabies viral } \\
\text { antigens from brain of animals. Comparison of dipstick dot ELISA with dFAT did not } \\
\text { produce non-specific false-positive results }\end{array}$ & $\begin{array}{c}\text { Jayakumar \& } \\
\text { Padmanaban (1994) }\end{array}$ \\
\hline 45. & 1991 & $\begin{array}{l}\text { Nondescript dogs were inoculated with beta-propiolactone (BPL) inactivated 5\% sheep } \\
\text { brain antirabies vaccine and local strain of street RABV was used for postvaccinal } \\
\text { challenge. The antibody response was found to be more IgM initially and more IgG } \\
\text { latterly. }\end{array}$ & $\begin{array}{c}\text { Jayakumar \& } \\
\text { Ramadass (1991) }\end{array}$ \\
\hline 46. & 1990 & $\begin{array}{l}\text { Peripheral blood leucocytes from unvaccinated dogs and dogs vaccinated } \\
\text { subcutaneously with BPL inactivated sheep brain antirabies vaccine were exposed in } \\
\text { vitro to rabies antigen. The CMI response could be detected as early as } 7 \text { days } \\
\text { postvaccination. It reached a peak by } 14 \text { days postvaccination followed by a decline. }\end{array}$ & $\begin{array}{c}\text { Jayakumar \& } \\
\text { Ramadass (1990) }\end{array}$ \\
\hline 47. & 1989 & $\begin{array}{l}\text { Both the tests FAT and RREID showed efficiency level of } 100 \% \text { and equally sensitive } \\
\text { to detect RABV antigens from brain and salivary glands of experimentally infected and } \\
\text { rabies suspected dogs. }\end{array}$ & $\begin{array}{l}\text { Jayakumar et al. } \\
\text { (1989) }\end{array}$ \\
\hline 48. & 1976 & $\begin{array}{l}\text { Transmission of rabies from wild animal (wolf) to humans and domestic animals, and } \\
\text { possibility of oral route of rabies infection described. }\end{array}$ & $\begin{array}{l}\text { Shah \& Jaswal } \\
\quad(1976)\end{array}$ \\
\hline 49. & 1968 & $\begin{array}{l}\text { Bandicota malabarica played significant role in the transmission of rabies among dogs } \\
\text { in the city of Madras. }\end{array}$ & D'Souza et al. (1968) \\
\hline
\end{tabular}

control program. To date, 19.1 million anti-rabies vaccines have been distributed and 5 million have been directly provided to eighteen countries to aid their national vaccination programmes (OIE, 2016). The Global Alliance for Rabies Control (GARC) is a non-profit organization dedicated to arrest human deaths from rabies and to relieve the disease burden in animal population. For World Rabies Day 2015, GARC and the rabies stakeholders (FAO/OIE/WHO) published the Rationale for investing in the global elimination of dog-mediated human rabies which directs countries to invest in sustainable and cost-effective control programs for global eradication from dog-mediated human rabies which is feasible through mass immunization of dogs. The rabies stakeholders are of the strategy to achieve no deaths from dog borne rabies by 2030. In sustenance of this goal, the World Rabies Day 2017, the theme was decided as Rabies: Zero by 30. The goal has been set by major international agencies, include the WHO, OIE, FAO of the United Nations and GARC. The main goal is to reach "zero human deaths from canine rabies by 2030 " (GARC, 2017).

Many agencies are engaged in rabies control program in India such as Ministry of Health (central and state), Ministry of Agriculture (central and state), State Animal Husbandry Departments (AHDs), Animal Welfare Board (AWB), Local
Civic Bodies, NIMHANS, Government veterinary colleges, etc. Pilot scheme on prevention and control of human rabies had been initiated on 2008 to 2012 by NCDC, MoHFW, GOI. It implemented in five cities including Ahmedabad, Bangalore, Delhi, Pune and Madurai (Rahman, 2011). Many NGO's are also engaged in rabies control such as Association for Prevention and Control of Rabies in India (APCRI), Rabies in Asia Foundation (RIA), etc. which initiated major projects for control of rabies (Rahman, 2011). The GARC and Commonwealth Veterinary Association (CVA) are also supporting for rabies control. Village Adoption Project was introduced and sponsored by NGO's like GARC, RIA and CVA to create awareness about rabies to reduce the frequency of human as well as animal rabies through improved educational awareness and mass immunization of dogs. Ten villages surrounding Bangalore and Pune were selected and huge number of medical and veterinary practitioners are working collaboratively in the selected villages to educate the people and to immunize the dogs (stray and supervised/restricted pet dogs) (Rahman, 2011).

Most recently, a global health-care company, namely ScheringPlough Corporation sponsored two projects in in India to reduce the incidence of human and animal rabies through improved educational awareness and mass vaccination of dogs. The 
company will donate $\$ 200,000$ and rabies vaccine from Intervet/Schering-Plough for successful implementation of the projects in 10 villages surrounding Bangalore and Pune (WHO, 2009). The Karuna Animal Welfare Association (Bangalore) is also actively participating in rabies control program (Rahman, 2011). The input of nongovernmental foundations like the Rabies in Asia Foundation, Sonadi the APCRI and the Animal Welfare Board of India is very much appreciable. Other programmes launched in different states of India to initiate mass vaccination of dogs (both domestic and stray) and control of rabies are described below

\subsection{Sikkim Anti-Rabies and Animal Health (SARAH) Programme}

The SARAH programme is a state-wide animal birth control and anti-rabies program initiated in 2005 in Gangtok. It is also an animal welfare and public health proposal of the Department of Animal Husbandry Livestock, Fisheries and Veterinary Services (Government of Sikkim) working collaboratively with the Francebased NGO Foundation Brigitte Bardot (FBB), Australia-based NGO, Vets Beyond Borders (VBB) and the Sikkim Society for Prevention of Cruelty of Animals (SSPCA) to make Sikkim rabies free. The SARAH programme aims on the protection of ecosystem and public health by controlling the street dog and cat population of Sikkim in a sustainable, humane and benevolent manner. The SARAH has been working tirelessly since its initiation because of that no human deaths due to rabies have been reported since 2006 until March, 2016. In 2015, Sikkim government became the first state in India to issue a notification that rabies is a reportable or notifiable disease in both animals and human. Since the inception of SARAH, more than 37,500 animal birth control surgeries, 24,571 doses of rabies vaccine, and 113 doses of distemper vaccine were administered under SARAH project. Further, 17,526 animals vaccinated during the $6^{\text {th }}$ statewide annual rabies vaccination campaign in 2015. In addition, 31 schools including one monk school were visited to provide education on dog bite prevention, post bite management, animal welfare and rabies control. SARAH worked to increase the public awareness of rabies and distemper through radio, television, newspapers, public meetings, school visits and world rabies day activities. Now, smaller and manageable street dog population in Sikkim and fewer stray puppies are in distress (Byrnes \& Bhutia, 2011; Byrnes et al., 2017).

\subsection{Mission Rabies in Goa}

Approximately 30,000 stray dogs are living in Goa. By 2013, Mission Rabies was started to make Goa rabies-free by 2018 with a perfect start of 10,000 vaccinations within a week. The Corporation, Municipalities and Panchayats will work with International Animal Welfare Organization (Mission Rabies) to reduce and manage the number of strays by sterilizing under animal birth control $(\mathrm{ABC})$ programme and vaccinating them against rabies. Mission Rabies in Goa formulated a programme with two main aims 1. Eradication of rabies disease; 2. Rabies free Goa. The programme was framed in 2 phases. The phase I is already completed by covering sterilization of 20,414 dogs and vaccination of 35,500 dogs. The phase II was started with the financial support of State Government in the form of Grant in Aid. Mission Rabies during the financial year 2016-17 achieved 55\% of dogs vaccinated were stray and $45 \%$ were owned. A total of 71 dogs were tested positive for rabies. Collaborative teamwork of volunteers, pet-owners and veterinarians did excellent job right from its launching, covering not only domesticated but also stray dogs. More interestingly, a smart phone application, Epicollect was used to update information about every single dog whereabouts, gender and health. It helped to locate and thereafter catch and vaccinate the stray dogs (Times of India, 2017).

\subsection{Pilot Education Project in Karnataka State}

In Karnataka, the project was introduced into the school curricula to make awareness among the school children about the disease and its control measures. Because more than $60 \%$ of all people who die of rabies are children in India. The main objective of the project is to relieve the burden of rabies in dogs in India and to reduce human rabies deaths. The target beneficiaries in this project are 54,529 primary schools with 2,52,875 teachers and 8.495 million students. Further 9,498 secondary schools with 92,287 teachers and 1.384 million students were beneficiaries. The goal of this project was incorporation of rabies education into 54,529 primary schools by 2013 and 9498 secondary schools in Karnataka state by 2015 (Rahman, 2011).

\subsection{Project on evaluation of neutralizing activity of monoclonal antibody combination against rabies}

Monoclonal antibodies (mAbs) capable of neutralizing various RABV variants could offer a low cost and safest rabies immunoglobulin (RIG). A project undertaken by WHO, in collaboration with WHO collaborating centres for rabies developed a cocktail of unique combinations of mAbs to replace RIG. The main aim of the project is to produce a safe and effective alternative therapy for rabies immunoglobulins by developing human monoclonal antibody cocktail for PEP, which can be used broadly and available at low price to the public of developing countries. The rabies mAbs and their hybridoma products being developed in the project have been transferred under Material Transfer Agreement to commercial manufacturers for development. The first rabies $\mathrm{mAb}$ to be licensed for commercial production is "Rabishield" in 2016 in India by the Serum Insitute of India in collaboration with MassBiologics, USA. The product was launched on the Indian market in 2017. 
Other products are in early preclinical development and some are in clinical trials (WHO, 2016).

\subsection{Animal Birth Control (ABC) Programme}

Animal Birth Control (Dogs) Rules, 2001 was started in November 2, 2001. Animal Birth Control (ABC) rules comes under the sub-section (1) of section 38 of the Prevention of Cruelty to Animals Act, 1960 (59 of 1960), Ministry of Culture, GOI. ABC Rules directs the municipalities work with animal welfare organisations to implement the $\mathrm{ABC}$ programme. $\mathrm{ABC}$ Rules conveys either killing or removal of dogs from any area is illegal. The ABC Rules also take steps for monitoring the dog bite cases to ascertain the reasons of dog bite, the area where it took place and whether it was from a stray or a pet dog. The ABC programme has been created by WHO for the control of street dog population and eradicate rabies (Reece \& Chawla, 2006). In ABC programme, more than one lakh stray dogs are sterilized and vaccinated against rabies every year. Currently, the $A B C$ Programme is started in more than 60 cities throughout the country, including metropolitan cities like Jaipur, Delhi, Mumbai, Chennai, Hyderabad, Bangalore, Kolkata, Jodhpur, etc. Since 2007, In Tamilnadu and Goa, the Animal Birth Control and AntiRabies Vaccination Programme have been successfully implemented for the entire state. Tamilnadu state is pioneering a new concept of a Participatory Model of the ABC Programme in 50 Municipalities and 5 Municipal Corporations, with $50 \%$ cost sharing by local bodies on participatory basis. Similarly, the Union Territory (UT) of Delhi has adopted the ABC Programme since 2008. Further, Tamilnadu has also been at the forefront of rabies control initiatives, having constituted the country's first State level Coordination Committee on Rabies Control and Prevention in January, 2009 (Kakkar et al., 2012; Annadurai et al., 2014). The Animal Welfare Board (AWB) of India is supporting the Animal Birth Control Anti-Rabies Programme in major metropolitan cities. $\mathrm{ABC}$ programme has been very effective in vaccinating the dogs and controlling the population of dogs and there by drastically reduced the rate of human rabies infection (Rahman, 2011). As a consequence of ABC programme, no incidence of rabies cases in humans was reported in Chennai during 2007 and reduced mortality, 120 deaths were reported during 1996 (Krishna, 2010).

\subsection{Pilot project on prevention and control of human rabies}

A pilot project on prevention and control of human rabies has been started in the $11^{\text {th }}$ five year plan during 2008-2011 by GOI in five cities (Ahmadabad, Bangalore, Delhi, Pune and Madurai). The project was launched by the NCDC being the nodal agency with a total budget of Rs. 3.26 crore. The main vision of this project is to bring together both medical and veterinary sectors for preventing human deaths due to rabies. The project activities include routine diagnosis of rabies in animals, post marketing serosurveillance of tissue culture anti-rabies vaccines, sero conversion studies in humans and animals, PEP treatment consultancy, training in laboratory techniques and rabies control are being executed by the NCDC.

\subsection{WHO/NCDC/APCRI national multicentric rabies survey of India}

The survey was published in May 2004 and reported Andaman and Nicobar Islands, one of the UTs of India and Lakshadweep are free of rabies. Majority of the human rabies deaths occurred in adults, males and in poor/low income groups in India. Based on the laboratory evidence, most common animal reservoirs for rabies are dogs, cattle, goats, cats and pigs and among the wild animals mongoose and jackal.

\subsection{National Rabies Control Program}

Under $12^{\text {th }}$ Plan (MoHFW, GOI, 2012-2017) the program was initiated with the object to control rabies deaths and transmission through dog bite. The program has two components namely, human component and animal component. All the states and UTs have been incorporated for human rabies component by adopting training of health professionals, i.d. inoculation of vaccines, surveillance of human rabies, educational awareness in community to PEP, animal bite management to the victims and strengthening of the laboratories. While, the animal component is regulated by the Animal Welfare Board of India, Ministry of Environment, Forest and Climate Change which is running a pilot study in Haryana and Chennai. In this component, street dog population survey, mass vaccination and stray dog population management and strengthening surveillance was carried out.

\section{Importance of community awareness}

Even after the implementation of many programmes for rabies control, lack of awareness is a major obstacle. Various studies have assessed the community knowledge and attitudes towards rabies, its prevention and control in an urban slum and the factors influencing rabies awareness in those areas through random sampling. The results of their study were really a matter of concern as only $54.1 \%$ of population was aware that rabies is a deadly disease and only half of the population knew about the proper post-bite first aid method. Furthermore, only $24.9 \%$ of the Indian dog population acknowledged the part of the community to control the stray dog population (Herbert et al., 2012). Hence along with control programmes, intensive public awareness programmes regarding the significance of rabies, vaccination and post-exposure first aid is to be implemented. 


\section{Conclusion and future perspectives}

Rabies can be contained on the basis of the results of diagnostic tests. Detection of the disease at its early stage is of paramount importance from the perspective of containment and preclusion of its spread to other suitable vectors. Stringent barrier measures are necessary because of its transmissible nature by saliva in skin and mucous membranes. The irreversibility of the disease condition after appearance of symptoms, various kinds of virus variants and the existence of wild animal reservoirs, all these at any point of interface can infect domestic creatures, thus multiplying the potential for transmission into human beings. All these issues sharply bring into focus the need to establish a surveillance mechanism that monitors the epidemiology of rabies in the wild animals. Such a mechanism would afford as with a better picture of disease progression in the wild and help to devise strategies to address possible outbreaks. From a veterinarian's perspective, these procedures are indispensable for two purposes, which include a chain of communication that permits both top down flow aimed at awareness and bottom up flow aimed at data gathering, and prophylaxis. On a rough estimate, approximately 30 million stray dogs population are there in India. Vaccinating that many dogs is not just a challenge, it is a test of community spirit, involvement of dedicated and skilled staff championing the project inside and outside the country. Ultimately, high-level political commitment is required. Veterinary and medical staffs must be conscious about the transmission of rabies to create the awareness in the public living in rural areas and persons working in abattoirs. Advanced diagnostic tests should be developed for early confirmatory diagnosis and various genotypes differentiation. Unexplored aspects of molecular biology and pathogenesis of rabies need to be explored for developing appropriate novel antiviral therapeutics like cytokine and siRNA therapies and newer generation vaccines. To control the rabies successfully, edible vaccines for domestic and wild ruminants should be developed.

\section{Funding}

This compiled review article by its authors are required no substantial funding to be stated.

\section{Acknowledgement}

All the authors are highly thankful to the Director, ICAR-IVRI for strengthening facilities for rabies research at IVRI, Izatnagar.

\section{Conflicts of interest}

All authors declare that there exist no commercial or financial relationships that could in any way lead to a potential conflict of interest.

\section{References}

Annadurai K, Danasekaran R, Mani G (2014) Rabies in India: A relook at the neglected rampant disease. The Journal of Neurobehavioral Sciences 1: 88-91.

Aravindh Babu RP, Manoharan S, Ramadass P, Chandran ND (2012) Evaluation of RT-PCR assay for routine laboratory diagnosis of rabies in post mortem brain samples from different species of animals. Indian Journal of Virology 23 : 392-6.

AravindhBabu RP, Manoharan S, Ramadass P (2014) Diagnostic evaluation of RT-PCR-ELISA for the detection of rabies virus. Indian Journal of Virology $25: 120-124$.

Aravindhbabu RP, Manoharan S, Ramadass P, Chandran ND (2011) Rabies in South Indian cows: An evidence of Sri Lankan rabies virus variant infection based on the analysis of partial nucleoprotein gene. Indian Journal of Virology 22 : 138-41.

Ashwath Narayana DH, Madhusudana SN, Sampath G, Tripathy RM, Sudarshan MK, Gangaboraiah, Ravish HS, Satapathy DM, Gowda G, Holla R, Ashwin BY, Padhi A, Manjula S, Patel PM (2014) Safety and immunogenicity study of a new purified chick embryo cell rabies vaccine Vaxirab-N (Pitman-Moore strain) manufactured in India. Human Vaccines \& Immunotherapeutics $10: 120-5$.

Baby J, Mani RS, Abraham SS, Thankappan AT, Pillai PM, Anand AM, Madhusudana SN, Ramachandran J, Sreekumar S (2015) Natural rabies infection in a domestic fowl (Gallus domesticus): A Report from India. PLoS Neglected Tropical Diseases 9: e0003942.

Badrane H, Bahloul C, Perrin P, Tordo N (2001) Evidence of two Lyssavirus phylogroups with distinct pathogenicity and immunogenicity. Journal of Virology 75: 3268-3276.

Balaram D, Taylor LH, Doyle KAS, Davidson E, Nel H (2016) World rabies day- a decade of raining awareness. Tropical Diseases, Travel Medicine and Vaccine 2: 1-9.

Bansal K, Singh CKK, Ramneek, Sandhu BS, Deka D, Dandale M, Sood NK (2012) Antemortem diagnosis of rabies from skin: comparison of nested RT-PCR with TaqMan real time PCR. Brazilian Journal of Veterinary Pathology 5: 116-119.

Briggs DJ, Dreesen DW, Wunner WH (2007) Vaccines. In: Jackson AC, Wunner WH, (Eds.), Rabies. San Diego (CA): Academic Press; Pp. 545-66.

Brookes VJ, Gill GS, Singh CK, Sandhu BS, Dhand NK, Singh BB, Gill JPS, Ward MP (2018) Exploring animal rabies 
endemicity to inform control programmes in Punjab, India. Zoonoses Public Health 65 : e54-e65.

Byrnes H, Bhutia T (2011) Sikkim anti-rabies and animal health programme - a local solution in a small state of India. EcoHealth 7: S61-S61.

Byrnes H, Britton A, Bhutia T (2017) Eliminating dog-mediated rabies in Sikkim, India: A 10-year pathway to success for the SARAH program. Frontiers in Veterinary Science 4:28.

CDC (1999) Mass treatment of humans who drank unpasteurized milk from rabid cows. Morbidity Mortality Weekly Report 48:228-230.

Chacko K, Parakadavathu RT, Al-Maslamani M, Nair AP, Chekura AP, Madhavan I (2016) Diagnostic difficulties in human rabies: A case report and review of the literature. Qatar Medical Journal 2:15. doi: 10.5339/qmj.2016.15.

Cherian S, Singh R, Singh KP, Reddy GM, Kumar GR, Sumithra TG, Singh RP (2015) Phylogenetic analysis of Indian rabies virus isolates targeting the complete glycoprotein gene. Infection, Genetics and Evolution 36: 333-338.

Cliquet F, Aubert M, Sagne L (1998) Development of a fluorescent antibody virus neutralisation test (FAVN test) for the quantitation of rabies-neutralising antibody. Journal of Immunological Methods 212:79-87.

Cliquet F, Gurbuxani JP, Pradhan HK, Pattnaik B, Patil SS, Regnault A, Begouen H, Guiot AL, Sood R, Mahl P, Singh R, Meslin FX, Picard E, Aubert MF, Barrat J (2007) The safety and efficacy of the oral rabies vaccine SAG2 in Indian stray dogs. Vaccine 25:3409-3418.

Coulon P, Derbin C, Kucera P, Lafay F, Prehaud C, Flamand A (1989) Invasion of the peripheral nervous systems of adult mice by the CVS strain of rabies virus and its avirulent derivative. Journal of Virology 63: 3550-3554.

Dacheux L, Reynes J-M, Buchy P, Sivuth O, Diop BM, Rousset D, Rathat C, Jolly N, Dufourcq JB, Nareth C, Diop S, Iehlé C, Rajerison R, Sadorge C, Bourhy H (2008) A reliable diagnosis of human rabies based on analysis of skin biopsy specimens. Clinical Infectious Diseases 47 : 1410-1417

Dandale M, Singh CK, Ramneek V, Deka D, Bansal K, Sood NK (2013) Sensitivity comparison of nested RT-PCR and TaqMan real time PCR for intravitam diagnosis of rabies in animals from urine samples. Veterinary World $6: 189-192$.

Dhingra V, Li X, Liu Y, Fu ZF (2007) Proteomic profiling reveals that rabies virus infection results in differential expression of host proteins involved in ion homeostasis and synaptic physiology in the central nervous system. Journal of Neurovirology 13: 107117.

Diksha K, Chauhan RS, Saminathan M, Dhama K, Malik YS (2018) Rabies immunization in animals and man - An overview. Journal of Immunology and Immunopathology $20: 1-13$.

D'Souza BA, Rao JR, Victor DA, Khader TG (1968) A preliminary investigation of the role of Bandicota malabarica in the transmission of rabies among dogs in the city of Madras. Indian Veterinary Journal $45: 633-8$.

Dumrongphol H, Srikiatkhachorn A, Hemachudha T, Kotchabhakdi N, Govitrapong P(1996) Alteration of muscarinic acetylcholine receptors in rabies viral infected dog brains. Journal of the Neurological Sciences 137: 1-6.

Fishbein DB, Sawyer LA, Reid-Sanden FL, Weir EH (1988) Administration of human diploid-cell rabies vaccine in the gluteal area. The New England journal of medicine $318: 124-5$.

Fishbein DB, Yenne KM, Dreesen DW, Teplis CF, Mehta N, Briggs DJ (1993) Risk factors for systemic hypersensitivity reactions after booster vaccination with human-diploid cell rabies vaccine-a nationwide prospective study. Vaccine 11: 1390-1394.

GARC (2017) Towards a rabies-free world as unparalleled global initiative gets underway. Available on https://rabiesalliance.org/news/towards-rabies-free-world access on 29th November, 2017

Gibbons RV (2002) Cryptogenic rabies, bats, and the question of aerosol transmission. Annals of Emergency Medicine 39:528536.

Gibson AD, Ohal P, Shervell K, Handel IG, Bronsvoort BM, Mellanby RJ, Gamble L (2015) Vaccinate-assess-move method of mass canine rabies vaccination utilising mobile technology data collection in Ranchi, India. BMC Infectious Diseases 15: 589.

Gluska S, Zahavi EE, Chein M, Gradus T, Bauer A, Finke S, Perlson E (2014) Rabies virus hijacks and accelerates the p75NTR retrograde axonal transport machinery. PLoS Pathogens 10 :e1004348.

Gould AR, Hyatt AD, Lunt R, Kattenbelt JA, Hengstberger S, Blackwell SD (1998) Characterisation of a novel lyssavirus isolated from Pteropid bats in Australia. Virus Research 54: 165187.

Gupta PK, Dahiya SS, Kumar P, Rai A, Patel CL, Sonwane AA, Saini M (2009) Sindbis virus replicon-based DNA vaccine 
encoding Rabies virus glycoprotein elicits specific humoral and cellular immune response in dogs. Acta Virologica 53 :83-8.

Gupta PK, Rai A, Rai N, Saini M (2005a) Immunogenicity of a plasmid DNA vaccine encoding glycoprotein gene of rabies virus CVS in mice and dogs. Journal of Immunology and Immunopathology 7: 58-61.

Gupta PK, Sharma S, Walunj SS, Chaturvedi VK, Raut AA, Patial S, Rai A, Pandey KD, Saini M (2005b) Immunogenic and antigenic properties of recombinant soluble glycoprotein of rabies virus. Veterinary Microbiology 108 : 207-214.

Gupta PK, Singh RK, Sharma RN, Rao YUB, Butchaiah G (2001) Preliminary Report on a single-tube, non-interrupted Reverse Transcription-Polymerase Chain reaction for the detection of rabies virus in brain tissue. Veterinary Research Communications $25: 239-247$.

Gupta PK, Sonwane AA, Singh NK, Meshram CD, Dahiya SS, Pawar SS, Gupta SP, Chaturvedi VK, Saini M (2012) Intracerebral delivery of small interfering RNAs (siRNAs) using adenoviral vector protects mice against lethal peripheral rabies challenge. Virus Research $163: 11-8$.

Hampson K, Coudeville L, Lembo T, Sambo M, Kieffer A, Attlan M, Barrat J, Blanton JD, Briggs DJ, Cleaveland S, Costa P (2015) Estimating the global burden of endemic canine rabies. PLOS Neglecetd Tropical Diseases 9 : e0003709.

Heaton PR, McElhinney LM, Lowings JP (1999) Detection and identification of rabies and rabies related viruses using rapid cycle PCR. Journal of Virological Methods 81:63-69.

Hellenbrand W, Meyer C, Rasch G, Steffens I, Ammon A (2005) Cases of rabies in Germany following organ transplantation. Eurosurveillance Weekly Release 10:050217.

Hemachudha T, Laothamatas J, Rupprecht CE (2002) Human rabies: a disease of complex neuropathogenetic mechanisms and diagnostic challenges. Lancet Neurology 1: 101-109.

Hemachudha T, Ugolini G, Wacharapluesadee S, Sungkarat W, ShuangshotiS, Laothamatas J (2013) Human rabies: neuropathogenesis, diagnosis and management. Lancet Neurology 12: 498-513.

Herbert M, Basha R, Thangaraj S (2012) Community perception regarding rabies prevention and stray dog control in urban slums in India. Journal of Infection and Public Health 5 : 374-380.

Hicks DJ, Fooks AR, Johnson N (2012) Developments in rabies vaccines. Clinical \& Experimental Immunology 169 : 199-204.
Hooper DC, Phares TW, Fabis MJ, Roy A (2009) The production of antibody by invading B cells is required for the clearance of rabies virus from the central nervous system. PLoS Neglected Tropical Diseases 3 : e535.

Iwata M, Komori S, Unno T, Minamoto N, Ohashi H (1999) Modification of membrane currents in mouse neuroblastoma cells following infection with rabies virus. British Journal of Pharmacology 126: 16919-1698.

Jackson AC, Rossiter JP, Lafon M (2006) Expression of Toll-like receptor 3 in the human cerebellar cortex in rabies, herpes simplex encephalitis, and other neurological diseases. Journal of Neurovirology 12: 229-234.

Jamadagni SB, Singh CK, Sandhu BS (2007) Histopathological alterations in brains of rabies infected buffaloes and cattle. Italian Journal of Animal Science $6: 872-874$.

Jayakumar R, Nachimuthu K, Padmanaban VD (1995) A Dot enzyme linked immunosorbent assay (Dot ELISA): comparison with standard fluorescent antibody test (FAT) for the diagnosis of rabies in animals. Comparative Immunology, Microbiology \& Infectious Diseases $18: 269-73$.

Jayakumar R, Padmanaban VD (1994) A dipstick dot enzyme immunoassay for detection of rabies antigen. Zentralblatt Fur Bakteriologie $280: 382-5$.

Jayakumar R, Ramadass P (1990) Studies on cell-mediated immune response to rabies virus immunization in dogs. Vaccine 8 $: 304-5$.

Jayakumar R, Ramadass P (1991) Immunoglobulin response to rabies virus immunization in dogs. Vaccine $9: 611-2$.

Jayakumar R, Ramadass P, Raghavan N (1989) Comparison of enzyme immunodiagnosis with immunofluorescence for rapid diagnosis of rabiesin dogs. Zentralblatt Fur Bakteriologie 271 : 501-3.

Jayakumar R, Thirumurugan G, Nachimuthu K, Padmanaban VD (1996) Detection of rabies virus antigen in animals by avidinbiotin dot ELISA. Zentralblatt Fur Bakteriologie 285 : 82-5.

Jemima EA, Manoharan S, Kumanan K (2014) Development and evaluation of a recombinant-glycoprotein-based latex agglutination test for rabies virus antibody assessment. Archives of Virology 159 : 1987-93.

Johnson N, Cunningham AF, Fooks AR (2010) The immune response to rabies virus infection and vaccination. Vaccine 28 : 3896-3901. 
Johnson RT (1965) Experimental rabies. Studies of vulnerability and pathogenesis using fluorescent antibody staining. Journal of Neuropathology and Experimental Neurology 14: 662-675.

Kakkar M, Venkataramanan V, Krishnan S, Chauhan RS, Abbas SS (2012) Moving from rabies research to rabies control: Lessons from India. PLOS Neglected Tropical Diseases 6: e1748.

Kaw A, Singh CK, Sandhu BS, Sood NK, Deka D, Awahan S (2011) Diagnosis of rabies in animals by nested RT-PCR. Indian Journal of Animal Sciences $81: 367-69$.

King AM, Lefkowitz E, Adams MJ, Carstens EB(2011) Virus taxonomy: ninth report of the International Committee on Taxonomy of Viruses. In: King AMQ, Adams MJ, Carstens EB, Leftkowitc EJ (Eds.), Virus taxonomy, Elsevier Publication.

Krishna SC (2010) The success of the ABC-AR programme in India. FAO, 20 August 2010. Available on http://www.fao.org access on $29^{\text {th }}$ November, 2017.

Kumar M, Singh RP, Mishra B, Singh R, Reddy GBM, Patel A, Saravanan R, Gupta PK (2010) Development of alternative approaches for in process quality control of rabies vaccine. Doctoral Thesis, submitted to Deemed University, IVRI, Izatnagar (India).

Kushwaha AN (2011) Combined effect of LPS and rabies immunoglobulin in pathogenesis of rabies in mouse model and study on spontaneous fetal brain affections in cattle and buffaloes. MVSc Thesis, submitted to Deemed University, IVRI, Izatnagar (India).

Kuzmin IV, Shi M, Orciari LA, Yager PA, Velasco-Villa A, Kuzmina N A, Streicker DG, Bergman DL, Rupprecht CE (2012) Molecular inferences suggest multiple host shifts of rabies viruses from bats to mesocarnivores in Arizona during 2001-2009. PLoS Pathogen 8:e1002786.

Lafon M, Megret F, Meuth SG, Simon O, Velandia Romero ML, Lafage M, Chen L, Alexopoulou L, Flavell RA, Prehaud C, et al (2008) Detrimental contribution of the immuno-inhibitor b7-h1 to rabies virus encephalitis. The Journal of Immunology 180: 75067515.

Li XQ, Sarmento L, Fu ZF ( 2005) Degeneration of neuronal processes after infection with pathogenic, but not attenuated, rabies viruses. Journal of Virology 79:10063-10068.

Madhu BP, Singh KP, Saminathan M, Singh R, Shivasharanappa N, Sharma AK, Malik YS, Dhama K. Manjunatha V (2016a) Role of nitric oxide in the regulation of immune responses during rabies virus infection in mice. VirusDisease 27 : 387-399.
Madhu BP, Singh KP, Saminathan M, Singh R, Tiwari AK Manjunatha V, Harish C Manjunathareddy GB (2016b) Correlation of inducible nitric oxide synthase (iNOS) inhibition with TNF- $\alpha$, caspase-1, FasL and TLR-3 in pathogenesis of rabies in mouse model. Virus Genes $52: 61-70$.

Madhusudana SN, Paul JP, Abhilash VK, Suja MS (2004) Rapid diagnosis of rabies in humans and animals by a dot blot enzyme immunoassay. International Journal of Infectious Diseases 8 : 339-345.

Madhusudana SN, Subha S, Thankappan U, Ashwin YB(2012) Evaluation of a direct rapid immunohistochemical test (dRIT) for rapid diagnosis of rabies in animals and humans. Virologica Sinica 27:299-302.

Madhusudana SN, Sukumaran SM (2008) Antemortem diagnosis and prevention of human rabies. Annals of Indian Academy of Neurology $11: 3-12$

Mani RS, Anand AM, Madhusudana SN (2016) Human rabies in India: an audit from a rabies diagnostic laboratory. Tropical Medicine \& International Health 21 :556-63.

Manickama R, Basheer MD, Jayakumar R (2008) Post-exposure prophylaxis (PEP) of rabies-infected Indian street dogs. Vaccine 26: $6564-8$

Manjunatha V, Singh KP, Saminathan M, Singh R, Shivasharanappa N, Umeshappa CS, Dhama K, Manjunathareddy GB (2017) Inhibition of MEK-ERK1/2-MAP kinase signalling pathway reduces rabies virus induced pathologies in mouse model. Microbial Pathogenesis $112: 38-49$.

Menager P, Roux P, Megret F, Bourgeois JP, Le Sourd AM, Danckaert A, Lafage M, Prehaud C, Lafon M (2009) Toll-like receptor 3 (TLR3) plays a major role in the formation of rabies virus Negri bodies. PLoS Pathogens. 5e1000315.

Menezes R (2008) Rabies in India. Canadian Medical Association Journal $178: 564-6$.

Meshram CD, Singh NK, Sonwane AA, Pawar SS, Mishra BP, Chaturvedi VK, Saini M, Singh RP, Gupta PK (2013) Evaluation of single and dual siRNAs targeting rabies virus glycoprotein and nucleoprotein genes for inhibition of virus multiplication in vitro. Archives of Virology 158: 2323-32.

Mifune K, Shichijo A, Marino Y, Takeughi E, Yamada A, Sakamoto K (1980) A mouse model for the pathogenesis and postexposure prophylaxis of rabies. Microbiology and Immunology $24: 835-845$. 
Milton AAP, Priya GB, Aravind M, Parthasarathy S, Saminathan M, Jeeva K, Agarwal RK (2015) Nosocomial infections and their surveillance in veterinary hospitals. Advances in Animal and Veterinary Sciences $3: 1-24$.

Müller T, Schuster P, Vos A, Selhorst T, Wenzel U, Neubert A (2001) Effect of maternal immunity on the immune response to oral vaccination against rabies in young foxes. American Journal of Veterinary Research 62: 1154-1158.

Murphy FA, Bauer SP, Harrison AK, Winn WC Jr (1973) Comparative pathogenesis of rabies and rabies-like viruses. Viral infection and transit from inoculation site to the central nervous system. Laboratory Investigation 28: 361-76.

Nagaraj T, Vasanth JP, Desai A, Kamat A, Madhusudana SN, Ravi V (2006) Ante mortem diagnosis of human rabies using saliva samples: Comparison of real time and conventional RTPCR techniques. Journal of Clinical Virology $36: 17-23$.

Nagarajan T, Mohanasubramanian B, Seshagiri EV, Nagendrakumar SB, Saseendranath MR, Satyanarayana ML, Thiagarajan D, Rangarajan PN, Srinivasan VA (2006) Molecular epidemiology of rabies virus isolates in India. Journal of Clinical Microbiology 44 : 3218-24.

Nagarajan T, Nagendrakumar SB, Mohanasubramanian B, Rajalakshmi S, Hanumantha NR, Ramya R, Thiagarajan D, Srinivasan VA (2009) Phylogenetic analysis of nucleoprotein gene of dog rabies virus isolates from Southern India. Infection, Genetics and Evolution 9(5): 976-82.

Nakamichi K, Inoue S, Takasaki T, Morimoto K, Kurane I (2004) Rabies virus stimulates nitric oxide production and CXC chemokine ligand 10 expression in macrophages through activation of extracellular signal-regulated kinases 1 and 2. Journal of virology $78: 9376-9388$.

NCDC (2015) National guidelines on rabies prophylaxis. Published by National Centre for Disease Control (Directorate General of Health Services), 22-Sham Nath Marg, Delhi, pp: 1$17 . \quad$ Available on www.ncdc.gov.in/writereaddata/mainlinkfile/File557.pdf access on 20th August, 2017.

NICD (2007) National Guidelines for Rabies Prophylaxis and Intra-dermal Administration of Cell Culture Rabies Vaccines. Published by National Institute of Communicable Diseases, Directorate General of Health Services, Ministry of Health \& Family Welfare, Government of India, New Delhi, pp: 1-27. Available on www.ncdc.gov.in/Rabies_Guidelines.pdf access on 20th August, 2017.
Ohara S, Sato S, Oyama K, Tsutsui KI, Iijima T(2013) Rabies virus vector transgene expression level and cytotoxicity improvement induced by deletion of glycoprotein gene. PloS One 8:e80245.

OIE (2016) The OIE rabies Vaccine Bank: A catalyst for rabies elimination strategies. Available on http://www.oie.int/en/for-themedia/press-releases/detail/article/the-oie-rabies-vaccine-bank-acatalyst-for-rabies-elimination-strategies/ access on 20th August, 2017.

Patel AC, Upmanyu V, Ramasamy S, Gupta PK, Singh R, Singh RP (2015) Molecular and immunogenic characterization of BHK21 cell line adapted CVS-11 strain of rabiesvirus and future prospect in vaccination strategy. Virus disease $26: 288$-96.

Patial S, Chaturvedi VK, Rai A, Saini M, Chandra R, Saini Y, Gupta PK (2007) Virus neutralizing antibody response in mice and dogs with a bicistronic DNA vaccine encoding rabies virus glycoprotein and canine parvovirus VP2. Vaccine $25: 4020-8$.

Pradhan HK, Gurbuxani JP, Cliquet F, Pattnaik B, Patil SS, Regnault A, Begouen H, Guiot AL, Sood R, Mahl P, Singh R, Picard E, Aubert MF, Barrat J, Meslin FX (2008) New steps in the control of canine rabies in India. Developments in Biologicals 131: 157-66.

Rahman SA (2011) Towards sustainable prevention of rabies at source: Case report India, In: Compendium of the OIE global conference on rabies control, Incheon, Republic of Korea: 2011, September 7 to 9 .

Ramya R, Verma PC, Chaturvedi VK, Gupta PK, Pandey KD, Madhanmohan M, Kannaki TR, Sridevi R, Anukumar B (2009) Poly (lactide-co-glycolide) microspheres: a potent oral delivery system to elicit systemic immune response against inactivated rabies virus. Vaccine $27: 2138-2143$.

Reddy GB, Singh R, Singh RP, Singh KP, Gupta PK, Mahadevan A, Shankar SK, Ramakrishnan MA, Verma R (2011) Molecular characterization of Indian rabies virus isolates by partial sequencing of nucleoprotein $(\mathrm{N})$ and phosphoprotein $(\mathrm{P})$ genes. Virus Genes 43 : 13-7.

Reddy MGB (2010) Molecular epidemiology and pathogenesis of Rabies. PhD Thesis, submitted to Deemed University, IVRI, Izatnagar (India).

Reece JF, Chawla SK (2006) Control of rabies in Jaipur, India, by the sterilisation and vaccination of neighbourhood dogs. Veterinary Record 159 : 379-83. 
Ren J, Yao L, Sun J, Gong Z (2015) Zagreb Regimen, an abbreviated intramuscular schedule for rabies vaccination. In: Papasian CJ (Ed.) Clinical and Vaccine Immunology: CVI. 22: 15.

Sandhu BS, Sood NK, Awahan S, Singh CK, Gupta K (2011) Immunohistochemistry, histopathology, quantitative morphometry of negri bodies in the brain of rabid animals. Indian Journal of Veterinary Pathology $35: 117-122$.

Savaliya BF, Mathakiya RA, Bhanderi BB, Jhala MK (2015) Evaluation of phenotypic factors for anti-rabies antibody in vaccinated pet dogs. Virus disease $26: 282-7$.

Saxena S, Dahiya SS, Sonwane AA, Patel CL, Saini M, Rai A, Gupta PK (2008) A sindbis virus replicon-based DNA vaccine encoding the rabies virus glycoprotein elicits immune responses and complete protection in mice from lethal challenge. Vaccine 26: 6592-6601.

Saxena S, Sonwane AA, Dahiya SS, Patel CL, Saini M, Rai A, Gupta PK (2009) Induction of immune responses and protection in mice against rabies using a self-replicating RNA vaccine encoding rabies virus glycoprotein. Veterinary Microbiology 136 : $36-44$

Sehgal S, Bhatia R (1985) Rabies: current status and proposed control programme in India. New Delhi: National Institute of Communicable Diseases

Servat A, Picard-Meyer E, Robardet E, Muzniece Z, Kylli Must $\mathrm{K}$, Cliquet $\mathrm{F}$ (2012) Evaluation of a rapid immunochromatographic diagnostic test for the detection of rabies from brain material of European mammals. Biologicals 40:61-66.

Shah U, Jaswal GS (1976) Victims of a rabid wolf in india: effect of severity and location of bites on development of rabies. The Journal of Infectious Diseases 134 : 25-9.

Shankar BP (2009) Advances in diagnosis of rabies. Veterinary World 2:74-78.

Shankar V, Dietzschold B, Koprowski H (1991) Direct entry of rabies virus into the central nervous system without prior local replication. Journal of Virology 65: 2736-2738.

Shankumar M (2010) Effect of lipopolysaccharide on molecular pathogenesis of rabies virus (CVS- 18 strain) in laboratory mouse model. MVSc Thesis, submitted to Deemed University, I.V.R.I., Izatnagar (India).

Sharma P, Singh CK, Narang D (2015) Comparison of immunochromatographic diagnostic test with Hheminested Reverse transcriptase polymerase chain reaction for detection of rabies virus from brain samples of various species. Veterinary World $8: 135-8$

Shivasharanappa N (2008) Involvement of TLR-3 and TLR-3 induced cytokines in the pathogenesis of rabies in experimental mouse model. MVSc. Thesis, submitted to Deemed University, I.V.R.I., Izatnagar (India).

Shivasharanappa N, Singh R, Singh KP, Madhu BP (2011) NK cell and macrophage activity in experimentally induced rabies in mice. Indian Journal of Veterinary Pathology35: 159-161.

Singh CK (2008) Current knowledge on pathology and pathogenesis of rabies and its status in the country. Indian Journal of Veterinary Pathology 32 : 143-149.

Singh CK, Sandhu BS (2008) Rabies in South Asia: epidemiological investigations and clinical perspective. Developments in Biologicals 131: 133-6.

Singh MP, Goyal K, Majumdar M, Ratho RK (2011) Prevalence of rabies antibodies in street and household dogs in Chandigarh, India. Tropical Animal Health and Production 43 : 111-4.

Singh NK, Meshram CD, Sonwane AA, Dahiya SS, Pawar SS, Chaturvedi VK, Saini M, Singh RP, Gupta PK (2014) Protection of mice against lethal rabies virus challenge using short interfering RNAs (siRNAs) delivered through lentiviral vector. Molecular Biotechnology 56 :91-101.

Singh R, Mehrotra ML, Shukla DC (1990) A note on diagnosis of rabies. VII Annual Conference of IAVP Sep., 17-19, Tirupati.

Singh R, Shukla DC, Khanna PN, Singh KP, Mehrotra ML(1995) An outbreak of rabies in cattle and buffaloes in Uttar Pradesh. The Indian Journal of Animal Science 65:166-168.

Singh R, Singh KP, Cherian S, Saminathan M, Kapoor S, Manjunatha Reddy GB, Panda S, Dhama K (2017) Rabies epidemiology, pathogenesis, public health concerns and advances in diagnosis and control: a comprehensive review. Veterinary Quarterly $37: 212-251$.

Singh VK, Tiwari KN, Mohan B, Mala C, Rana UV, Ichhpujani RL (2007) Humoral response to rabies vaccines in pet dogs. Journal of Communicable of Diseases 39: 109-11.

Smith JS (1996) New aspects of rabies with emphasis on epidemiology, diagnosis, and prevention of the disease in the United State. Clinical Microbiology Reviews 9:166-176.

Sonwane AA, Dahiya SS, Saini M, Chaturvedi VK, Singh RP and Gupta PK (2012). Inhibition of rabies virus multiplication by siRNA delivered through adenoviral vector in vitro in BHK-21 
cells and in vivo in mice. Research in Veterinary Science 93: 498-503.

Sudarshan MK, Mahendra BJ, Madhusudana SN, Narayana DA, Rahman A, Rao NS, X-Meslin F, Lobo D, Ravikumar K (2006) An epidemiological study of animal bites in India: results of a WHO sponsored national multi-centric rabies survey. Journal of Communicable Diseases 38: 32.

Suja MS, Mahadevan A, Madhusudhana SN, Vijayasarathi SK, Shankar SK (2009) Neuroanatomical mapping of rabies nucleocapsid viral antigen distribution and apoptosis in pathogenesis in street dog rabies--an immunohistochemical study. Clinical Neuropathology 28 : 113-24.

Sumit S (2017) Effect of inhibition of TLR-3 on pathogenesis of rabies in mouse model. MVSc. Thesis, submitted to Deemed University, I.V.R.I., Izatnagar (India).

Takayama N (2005) Clinical feature of human rabies. Nippon Rinsho 63:2175-2179.

Thoulouze MI, Lafage M, Yuste VJ, Kroemer G, Susin SA, Israel N, Lafon M (2003) Apoptosis inversely correlates with rabies virus neurotropism. Annals of the Aew York Academy of Sciences 1010: 598-603.

Times of India (2017) Mission Rabies nears completion, hopes to continue work in Goa. Updated: Apr 11, 2017, https://timesofindia.indiatimes.com/city/goa/mission-rabies-nearscompletion-hopes-to-continue-work-in-

goa/articleshow/58117812.cms

Tsiang H (1982) Evidence for an intraaxonal transport of fixed and street rabies virus. Journal of Neuropathology and Experimental Neurology 38: 286-296.

Tuffereau C, Benejean J, Blondel D, Kieffer B, Flamand A (1998) Low affinity nerve-growth factor receptor (P75NTR) can serve as a receptor for rabies virus. The EMBO Journal 17:7250-7259

Ugolini G (2008) Use of rabies virus as a transneuronal tracer of neuronal connections: implications for the understanding of rabies pathogenesis. Developmental Biology (Basel) 131: 493-506.

Ugolini G (2011) Rabies virus as a transneuronal tracer of neuronal connections. Advances in Virus Research 79: 165-202.

Vagheshwari DH, Bhanderi BB, Mathakiya RA, Jhala MK (2017) Sequencing and sequence analysis of partial nucleoprotein $(\mathrm{N})$ gene and phylogenetic analysis of rabies virus field isolates from Gujarat state, India. Virus disease 28: 320-327.
Vasanth JP, Madhusudana SN, Abhilash KV, Suja MS, Muhamuda K (2004) Development and evaluation of an enzyme immunoassay for rapid diagnosis of rabies in humans and animals. Indian Journal of Pathology and Microbiology 47: 574-578.

Velandia-Romero ML, Castellanos JE, Martínez-Gutiérrez M (2013) In vivo differential susceptibility of sensory neurons to rabies virus infection. Journal of Neurovirology 4: 367-375.

Vengatesan D, Raj GD, Raja A, Ramadass P, Gunaseelan L (2006) Detection of rabies virus antigen or antibody using flow cytometry. Cytometry Part B: Clinical Cytometry 70 : 335-43.

Verma A (2012) Evaluation of molecular diagnostic tests for rabies on brain tissues stored under varying conditions. MVSc. Thesis, submitted to Deemed University, IVRI, Izatnagar (India).

Warrell MJ, Warrell DA (2004) Rabies and other lyssavirus diseases. Lancet 363:959-969.

Wasniewski M, Cliquet F(2012) Evaluation of ELISA for detection of rabies antibodies in domestic carnivores. Journal of Virological Methods 179 :166-175.

WHO (2001) Strategies for the control and elimination of rabies in Asia. Report of a WHO interregional consultation. Report of the workshop on rabies control in Asian countries; p. 32.

WHO (2005) Expert Consultation on rabies. World Health Organization Technical Report Series 931: 1-88

WHO (2009) India's ongoing war against rabies. Bulletin of the World Health Organization 87 : 885-964

WHO (2013) Expert consultation on rabies. Second report. World Health Organization Technical Report Series 982: 1-139.

WHO (2014) WHO guide for rabies pre and post-exposure prophylaxis in human (updated 2014). Geneva: WHO. Available online at: http://www. who.int/rabies/WHO_Guide_Rabies_ Pre_Post_Exposure_Prophylaxis_Humans_2014. Pdf, Access on $20^{\text {th }}$ October, 2017.

WHO (2015) Rabies: Rationale for investing in the global elimination of dog-mediated human rabies. In Rabies: rationale for investing in the global elimination of dog-mediated human rabies.

WHO (2016) Rabies monoclonal antibodies post exposure prophylaxis. www.who.int/rabies/resources/Summary-rabiesmAbs-for-Web_Dec2016.pdf Access on 20 ${ }^{\text {th }}$ October, 2017. 
Winkler WG, Fashinell TR, Leffingwell L, Howard P, Conomy JP (1973) Airborne rabies transmission in a laboratory worker. Journal of American Medical Association 226:1219-1221.

Wirblich C, Schnell MJ (2011) Rabies virus (RV) glycoprotein expression levels are not critical for pathogenicity of RV. Journal of Virology 85: 697-704.

Yan X, Prosniak M, Curtis MT, Weiss ML, Faber M, Dietzschold B, Fu ZF (2001) Silver-haired bat rabies virus variant does not induce apoptosis in the brain of experimentally infected mice. Journal of Neurovirology $7: 518-27$.

Yang DK, Kim HH, Lee KW, Song JY (2013) The present and future of rabies vaccine in animals. Clinical and Experimental Vaccine Research $2: 19-25$.
Yousaf MZ, Qasim M, Zia S, Khan Mu, Ashfaq UA, Khan S (2012) Rabies molecular virology, diagnosis, prevention and treatment. Virology Journal 9:50.

Zeiler FA, Jackson AC (2016) Critical appraisal of the Milwaukee protocol for rabies: this failed approach should be abandoned. Canadian Journal of Neurological Sciences 43(1): 44-51.

Zhang G, Wang H, Mahmood F, Fu ZF (2013) Rabies virus glycoprotein is an important determinant for the induction of innate immune responses and the pathogenic mechanisms. Veterinary Microbiology 162: 601-613.

Zhang S, Liu Y, Fooks AR, Zhang F, Hu R (2008) Oral vaccination of dogs (Canis familiaris) with baits containing the recombinant rabies-canine adenovirus type-2 vaccine confers long-lasting immunity against rabies. Vaccine 26:345-350. 